\title{
Non-coding RNAs: long non-coding RNAs and microRNAs in endocrine-related cancers
}

\author{
Carolyn M Klinge
}

Department of Biochemistry \& Molecular Genetics, Center for Genetics and Molecular Medicine, University of Louisville School of Medicine, Louisville, Kentucky, USA

Correspondence should be addressed to C M Klinge: carolyn.klinge@louisville.edu

\begin{abstract}
The human genome is 'pervasively transcribed' leading to a complex array of noncoding RNAs (ncRNAs) that far outnumber coding mRNAs. ncRNAs have regulatory roles in transcription and post-transcriptional processes as well numerous cellular functions that remain to be fully described. Best characterized of the 'expanding universe' of ncRNAs are the 22 nucleotide microRNAs (miRNAs) that base-pair to target mRNA's $3^{\prime}$ untranslated region within the RNA-induced silencing complex (RISC) and block translation and may stimulate mRNA transcript degradation. Long non-coding RNAs (IncRNAs) are classified as >200 nucleotides in length, but range up to several $\mathrm{kb}$ and are heterogeneous in genomic origin and function. IncRNAs fold into structures that interact with DNA, RNA and proteins to regulate chromatin dynamics, protein complex assembly, transcription, telomere biology and splicing. Some IncRNAs act as sponges for miRNAs and decoys for proteins. Nuclear-encoded IncRNAs can be taken up by mitochondria and IncRNAs are transcribed from mtDNA. Both miRNAs and IncRNAs are dysregulated in endocrine cancers. This review provides an overview on the current understanding of the regulation and function of selected IncRNAs and miRNAs, and their interaction, in endocrine-related cancers: breast, prostate, endometrial and thyroid.
\end{abstract}
Key Words
- miRNA
- InCRNA
- ncRNA
- transcription
- translation

\section{Introduction}

Cancer is a disease of the genome in which tumors have a constellation of genomic and epigenetic alterations that drive their clinical behavior and patient prognosis (Macconaill \& Garraway 2010). The Central Dogma proposed by Francis Crick in 1958 envisioned that information flowed from DNA to mRNA, which is translated into functional proteins with the assistance of tRNA and rRNA (reviewed in Morris \& Mattick 2014, Jarroux et al. 2017). With time, additional classes of RNA that have important regulatory roles in cellular biology were discovered: short nuclear and small nucleolar RNAs (snRNAs and snoRNAs), followed by microRNAs (miRNAs) and long non-coding RNAs (lncRNAs). The Encyclopedia of DNA Elements (ENCODE) Consortium was started in 2003 as an international collaboration funded by the National Human Genome Institute (NHGRI). Analysis of the human genome revealed that while $\sim 85 \%$ is transcribed, only $\sim 1 \%$ is protein-coding mRNA (ENCODE Project Consortium 2012, Djebali et al. 2012, Dykes \& Emanueli 2017). The GENCODE consortium (https:// www.gencodegenes.org/) is a subproject of ENCODE that produces high-quality reference gene annotation and experimental validation. The current GENECODE, version 27 of the human genome includes 58,288 genes; 200,401 total transcripts; 19,826 protein-coding genes; 15,778 lncRNAs; 14,694 pseudogenes; 7569 small non-coding 
RNA (ncRNA) genes and 1881 miRNAs. Most (85\%) small ncRNAs are snRNAs, snoRNAs, miRNAs and tRNAs (Djebali et al. 2012). In addition to GENECODE, the FANTOM (Functional Annotation of Mammalian Genomes) project is creating a comprehensive catalog of transcripts encoded in human, mouse, rat, dog, Rhesus monkey and chicken genomes (http://fantom.gsc.riken.jp) (Kawaji et al. 2017). Analysis of data from FANTOM5 identified 27,919 human lncRNA genes with high-confidence 5' ends and provided evidence that $69 \%(19,175)$ are functional (Hon et al. 2017). The history of the discovery of regulatory RNAs, notably the ncRNAs, has been reviewed (Morris \& Mattick 2014).

The advent of next-generation sequencing (NGS) by RNA sequencing (RNA-seq), also called 'whole transcriptome shotgun sequencing' and 'deep RNA-seq', has allowed characterization of the cellular transcriptomes, i.e., the entire spectrum of RNAs produced in a cell type (Wolf 2013), resulting in a glut of data that can be mined by investigators. One database of transcriptomes of potential interest for readers of this review is the NURSA website (www.nursa.org). The transcriptome includes mRNA, rRNA and tRNA; and the ncRNAs: miRNAs, enhancer RNAs (eRNAs), endogenous small-interfering RNAs (siRNAs), Piwi-interacting RNAs (piRNAs), circular RNAs (circRNAs) and lncRNAs (Marrone et al. 2014). Table 1 highlights features of these ncRNAs and their roles in cellular processes. The function of piRNAs and snoRNAs in endocrine-related cancers was reviewed (Venkatesh et al. 2015). miRNAs are best characterized for their gene silencing of target mRNA by complementary base-paring with the 3'UTR within the RNA-induced silencing complex (RISC) to repress translation and/or cause mRNA degradation (Muluhngwi \& Klinge 2015). Like miRNAs, siRNAs and piRNAs bind argonaute (AGO) family members and base-pair with target RNA to cause RNA degradation and/or translation repression (Watanabe $\&$ Lin 2014). Studies have shown that RNA polymerase (pol) II-mediated transcriptional activity at gene enhancers is 'pervasive' and bidirectional, generally producing transcripts in both directions including short eRNAs that play roles in enhancer-promoter interactions (reviewed in Lam et al. 2014). Enhancers are relatively insensitive to position and distance of their target genes and about half are intragenic, which can result in inhibition or attenuation of nascent transcript elongation (Cinghu et al. 2017). circRNAs are usually formed by noncannonical splice reactions and reside in the cytoplasm where one circRNA, CDR1AS, regulates miR-7 stability and transport in neurons (Piwecka et al. 2017).
Both miRNAs and lncRNAs are epigenetic regulators of human cancers (Liz \& Esteller 2016). Moreover, these RNAs are chemically modified, e.g., by post-transcriptional methylation on $\mathrm{N} 6$ of adenosine $\left(\mathrm{m}^{6} \mathrm{~A}\right)$, which alters their activities, providing an additional layer of regulation termed 'epitranscriptomics' (Li et al. 2016c). Many more papers have been published on miRNAs than IncRNAs in endocrine cancers (Fig. 1). This review provides a brief overview of the identity, regulation and roles of miRNAs and lncRNAs in selected endocrine-related cancers. Because of the scope of published literature on these topics, this review is not a comprehensive analysis of lncRNAs and miRNAs in breast, prostate, endometrial and thyroid cancers. The reader is provided with citations to recent reviews and primary literature for further information.

\section{IncRNAs: classification and functional activities}

lncRNAs are defined as ncRNAs of $>200$ nucleotides that are transcribed by RNA pol II from regulatory regions including promoter upstream elements and technically include eRNAs (Andersson et al. 2014). However, eRNAs differ from IncRNAs by being shorter $(<2 \mathrm{kbp})$, without being spliced and are not polyadenylated (Kim et al. 2015). By total cellular RNA mass, IncRNA constitutes only $0.03-0.2 \%$ while mRNA constitute $3-7 \%$ (Dykes \& Emanueli 2017). IncRNAs are classified based on their genomic organization: (1) intergenic lncRNAs (lincRNAs) are transcribed between two protein-coding genes; (2) intronic lncRNAs are transcribed from introns of protein-coding genes; (3) overlapping lncRNAs, as the name implies, constitute transcripts that overlap known protein-coding genes; and (4) antisense (as) lncRNAs are transcribed in a direction opposite that of the proteincoding gene (Peng et al. 2017b) (Fig. 2). Pseudogenes that arise from DNA duplication of coding genes followed by inactivating mutations that render the pseudogene non-coding are transcribed as lncRNAs and sequester some of the miRNAs that interact with conserved miRNA response elements (MREs) in the functional gene (Dykes \& Emanueli 2017). However, given the low levels of IncRNA, the functional role of IncRNAs as 'miRNA sponges' by base-pairing and thus blocking miRNA-MRE binding to target mRNA-3'UTRs, is debated. It seems likely that more highly expressed lncRNAs (with higher FKPM (Fragments Per Kilobase Million reads in RNA-seq)) would be more likely to act as competing endogenous RNA (ceRNA) to sequester miRNAs (Dykes \& Emanueli 2017). Additional classifications of lncRNAs are by (1) length, 
Table 1 Summary of ncRNAs in humans, excluding rRNA and tRNA, with their size, cellular location, aspects of biogenesis, function, citations for reviews for roles in various endocrine-related cancers and websites.

\begin{tabular}{|c|c|}
\hline ncRNA & $\begin{array}{l}\text { Description, size, location, function and example of findings } \\
\text { in endocrine cancers }\end{array}$ \\
\hline miRNA & $\begin{array}{l}\text { - } 21 \text { nt ssRNA } \\
\text { - } \quad \text { Transleus and cytoplasm } \\
\text { ing one or more inverted repeats or hairpins } \\
\text { - } \quad \text { Form complimentary base-pairs with the } 3^{\prime} \text { untranslat- } \\
\text { ed region of target mRNAs within RISC block transla- } \\
\text { tion and/or stimulate mRNA transcript degradation } \\
\text { - } \text { Expressed in a tissue-specific manner } \\
\text { - Most are considered highly stable } \\
\text { - IsomiRs are sequence variants of the canonical miRNA } \\
\text { currently in the miRBase generated from a single } \\
\text { miRNA locus by template and non-template variants } \\
\text { - miRNAs in endocrine cancers have been reviewed: thy- } \\
\text { roid, adrenal, pancreatic, and pituitary cancers (Lima } \\
\text { et al. 2017); endocrine-resistant breast (Muluhngwi } \\
\text { \& Klinge 2015); prostrate, ovarian, and breast (Smith } \\
\text { et al. 2017) }\end{array}$ \\
\hline circRNAs & $\begin{array}{l}\text { Circular RNAs: } 4 \text { types: exonic circRNAs (ecircRNA), circular } \\
\text { RNAs from introns, exon-intron circRNAs (EIciRNA) and } \\
\text { intergenic circRNAs (Meng et al. 2017) } \\
\text { - Cytoplasm } \\
\text { - Generally formed by alternative splicing of pre-mRNA } \\
\text { in which an upstream splice acceptor is joined to a } \\
\text { downstream splice donor in a process known as 'backs- } \\
\text { plicing' (Barrett \& Salzman 2016) } \\
\text { - Expressed in thousands of human genes } \\
\text { - Stable: half-life }>48 \mathrm{~h} \\
\text { - Expressed in a cell-type and tissue-specific manner } \\
\text { - Act as miRNA sponges, interact with RNA-binding pro- } \\
\text { - } \text { teins, can be positive regulators of their parental genes } \\
\text { - circRNAs were identified in human papillary thyroid } \\
\text { cancer (Peng et al. 2017a) and in human breast tumors } \\
\text { (Liang et al. 2017) }\end{array}$ \\
\hline eRNAs & $\begin{array}{l}\text { Enhancer RNAs are produced from enhancers (Lam et al. } \\
\text { 2014) } \\
\text { - Nuclear, 5'methyl-capped, +/- polyadenylation } \\
\text { - } 800-2000 \text { bp } \\
\text { - } \text { Low stability and abundance } \\
\text { facility function in cis to increase transcription by looping between the enhancer and } \\
\text { promoter } \\
\text { - May facilitate histone modifications and chromatin } \\
\text { remodeling (Li et al. 2016b) } \\
\text { CGA, the common } \alpha \text {-subunit of LH, FSH, and TSH is } \\
\text { regulated by an eRNA (Nagarajan et al. 2015) }\end{array}$ \\
\hline piRNA & $\begin{array}{l}\text { PIWI-interacting RNAs } \\
\text { - } 24-32 \text { nt ss RNAs } \\
\text { - } \quad \text { Nerived from piRNA clusters } \\
\text { - } \quad \text { Bind PIWI subfamily of Argonaut proteins } \\
\text { - Involved in gene silencing (Luteijn \& Ketting 2013) } \\
\text { - Protect genome against instability by repressing trans- } \\
\text { poson activity via transcriptional gene silencing } \\
\text { - Expression mostly restricted to germ cells } \\
\text { The transposable element (TE) landscape in postnatal } \\
\text { human testis is matched by a relevant piRNA repertoire } \\
\text { to silence TEs in spermatogenesis (Gainetdinov et al. } \\
\text { 2017) }\end{array}$ \\
\hline
\end{tabular}

\section{Websites}

miRBase http://www.mirbase.org

miRTarBase: experimentally validated miRNA-target Interactions http://miRTarBase.mbc.nctu.edu.tw miRAD: intragenic miRNA database http://bmi.ana. med.uni-muenchen.de/miriad/

MAGIA http://gencomp.bio.unipd.it/magia/start/ TargetScanHuman search for predicated miRNA targets http://www.targetscan.org/vert_71/ IsomiRage http://cru.genomics.iit.it/lsomirage/

CIRCexplorer (Yang et al. 2017c) https://omictools. com/circexplorer-tool CIRI https://omictools.com/ciri-tool

CircRNA_finder https://omictools.com/circrna-findertool

MapSplice 2 for mapping RNA-seq data to ref genome for splice junction discovery http://www. netlab.uky.edu/p/bioinfo/MapSplice2

CirclncRNAnet (RRIC:SCR_015794) https://dknet.org/ scicrunch/Resources/record/ nlx_144509-1/2d26f6b1-5909-5066-a261a05ca13e12d9/search?mc_cid=23e8e71213\&mc eid=ed4995675c 
Table 1 Continued.

\begin{tabular}{|c|c|}
\hline ncRNA & $\begin{array}{l}\text { Description, size, location, function and example of findings } \\
\text { in endocrine cancers }\end{array}$ \\
\hline Endo-siRNA & $\begin{array}{l}\text { Endogenous small-interfering RNAs } \\
\text { - } 20-23 \text { nt } \\
\text { - Cytoplasmic } \\
\text { - Processed from dsRNAs by DICER } \\
\text { - Have a 3' 2-nt overhang } \\
\text { - } \text { Morm an effector complex with AGO1 or AGO2 (Piatek } \\
\text { - Detected in mammalian embryonic stem cells, oocytes } \\
\text { and spermatocytes (Hilz et al. 2016) }\end{array}$ \\
\hline IncRNAs & 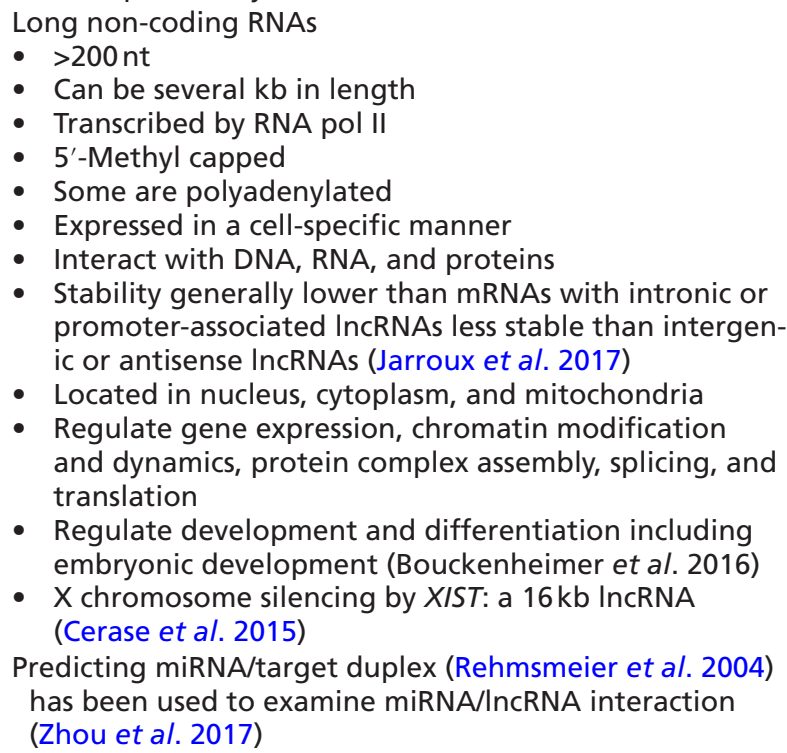 \\
\hline
\end{tabular}

Websites

HUGO Gene Nomenclature Committee IncRNAs
https://www.genenames.org/cgi-bin/genefamilies/
set/788
NONCODE v. 5.0 ncRNA http://www.noncode.org/
IncRNASNP2 is a database of functional SNPs and
mutations in human and mouse IncRNAs http://
bioinfo.life.hust.edu.cn/IncRNASNP2
Websites reviewed in (Fritah et al. 2014)
LNCipedia 4.1 https://lncipedia.org/ (146,742 human
annotated IncRNAs)
DIANA-LncBase v.2 includes miRNA:IncRNA
interactions (Paraskevopoulou et al. 2016)
NONCODE v5.0 http://www.noncode.org/index.php

http://bibiserv.techfak.uni-bielefeld.de/rnahybrid/ e.g. very long lincRNA (vlincRNA); (2) being encoded within specific DNA regulator elements and loci, e.g., in telomeres (TERRA), centromeres, rDNA loci (PAPAS) or 3'UTR-associated RNAs (uaRNA); (3) biogenesis pathway; (4) subcellular localization or origin, e.g., nuclear, cytoplasmic or mitochondrial; (5) function, e.g., scaffold IncRNA (HOTAIR) and (6) association with specific biological processes (Jarroux et al. 2017).

IncRNAs show chromatin marks that are typical of transcribed coding genes: H3K4me3 for transcription initiation and H3K36me3 for elongation (Rinn \& Chang 2012) and are regulated by transcription factors binding to their promoters. IncRNAs are alternatively spliced, thus generating isoforms. IncRNAs associated with enhancer regions can act in cis, leading to increased transcription of neighboring genes, including other lncRNAs (Ørom Ulf \& Shiekhattar 2013). Some lncRNAs directly bind target mRNAs which can either target the mRNA for degradation or stabilize the transcript. A class of lncRNAs called 'activating ncRNA-as' specifically activate neighboring coding genes by binding to specific DNA sequences while associating with the Mediator-cohesin complex to loop enhancer/promoter regions (Dykes \& Emanueli 2017). Despite their length, which can be several kb, lncRNAs do not have a functional protein-encoding capacity, i.e., those that contain small open reading frames (ORFs) do not form a template for translation (Hu et al. 2012).

As indicated in the Introduction, the number of human lncRNAs varies between databases. For example, the NONCODE v5 database includes 96,308 lncRNA genes (Xiyuan et al. 2017) compared with 15,778 in GENECODE and 27,919 in FANTOM (Hon et al. 2017). lncRNAs are expressed in a tissue-specific manner and are usually 5'-end capped and some are 3 '-end polyadenylated ( $\mathrm{Li}$ et al. 2016a). Some 1ncRNAs, e.g., MALAT1 and NEAT1, have a triple-helical structure at the 3 'end that protects them from degradation. The landscape of isoforms of lncRNAs adds to the complexity of understanding lncRNA function (Ziegler \& Kretz 2017). In addition, the presence of lncRNA modifications and lncRNA editing has been reported and associated with structural and functional changes, which further increases the variety of 


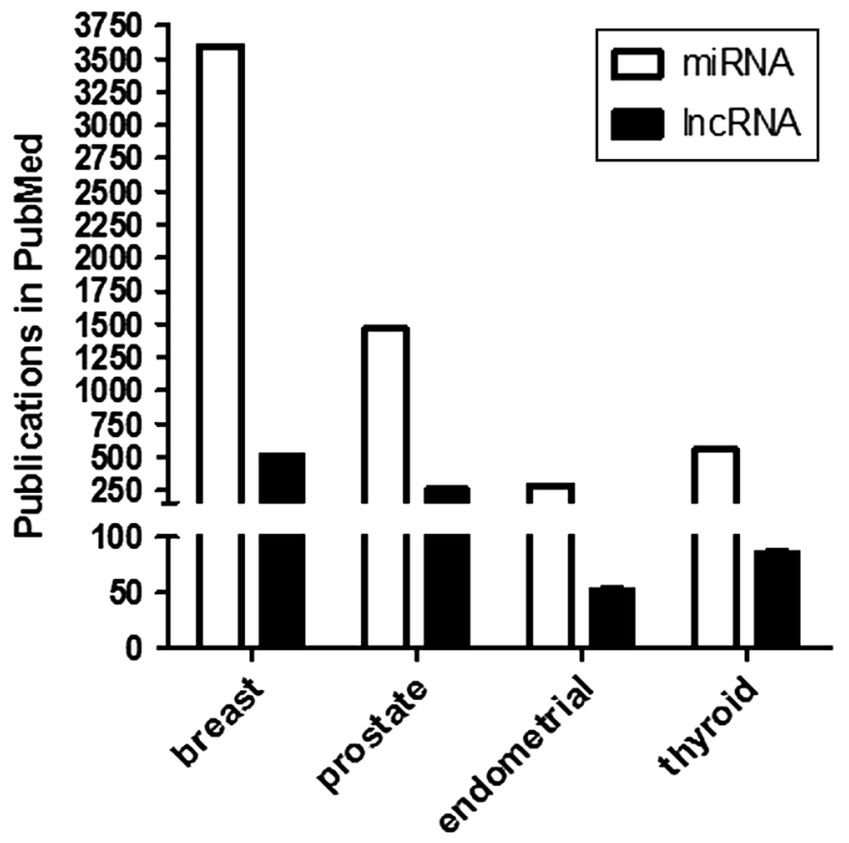

cancer type

Figure 1

PubMed referenced papers on miRNAs and IncRNAs for endocrine cancers. Values were determined on November 28, 2017.

lncRNAs (reviewed in Ziegler \& Kretz 2017). For example, $\mathrm{m}^{6} \mathrm{~A}$ modification is required for XIST1-mediated gene silencing (Patil et al. 2016). Accumulating evidence implicates roles for dysregulated IncRNAs in cancer (Huarte 2015), autoimmune and inflammatory diseases (Chen et al. 2017), including type 1 (Mirza et al. 2017) and type 2 diabetes (Motterle et al. 2016, Leti \& DiStefano 2017) and other diseases.

lncRNA function depends on cellular location (Fig. 3). IncRNAs fold in various conformations that allows interaction with RNA, DNA and proteins to regulate nuclear, cytoplasmic (Delas \& Hannon 2017) and mitochondrial function (De Paepe et al. 2017). IncRNAs regulate processes including gene transcription, chromatin dynamics, chromatin looping, histone modifications, telomere biology, protein complex assembly, RNA splicing and translation (Mercer \& Mattick 2013). Within the nucleus, specific lncRNAs, including AIRN, ANRIL, HOTAIR and XIST interact with specific transcription factors, enzymes involved in DNA methylation (DNMT1), chromatin modification (HDAC1, EZH2 (a lysine $\mathrm{N}$-methyltransferase)) and polycomb repressive complex 2 (PRC2) (Nakagawa \& Kageyama 2014). IncRNAs are involved in assembly of active e.g., NEAT1, or repressed, e.g., XIST, nuclear chromatin domains in a cell-dependent manner (Rinn \& Guttman 2014). NEAT1 is an architectural RNA that interacts with $>60$ RNA-binding proteins and transcription factors in paraspeckles (Yamazaki \& Hirose 2015). NEAT1 is also acts as a 'sponge' for miR-214 and mIR-101, thus upregulating targets of these miRNAs, i.e., HMGA1 and EZH2, respectively (Qian et al. 2017, Wang et al. 2017a,c). Thus, many biological processes are regulated by lncRNAs including cell differentiation, proliferation and survival.

Functional roles of IncRNAs in the cytoplasm including acting as a scaffold. For example, the RNA stemloop structure of LINC01139 (also called LINK-A) provides a scaffold for HBEGF (heparin-binding epidermal growth factor (EGF)-like growth factor)-triggered, EGF receptor (EGFR):GPNMB (glycoprotein NMB) heterodimermediated recruitment of PTK6 (protein tyrosine kinase 6, also called BRK) and LRRK2 (leucine-rich repeat kinase-2) for phosphorylation and stabilization of HIF-1 $\alpha$ in MDA-MB-231 triple-negative breast cancer (TNBC) cells (Lin et al. 2016). LINC01139 also binds phosphatidylinositol-3,4,5-trisphosphate (PIP3) and

Intergenic IncRNA (lincRNAs)

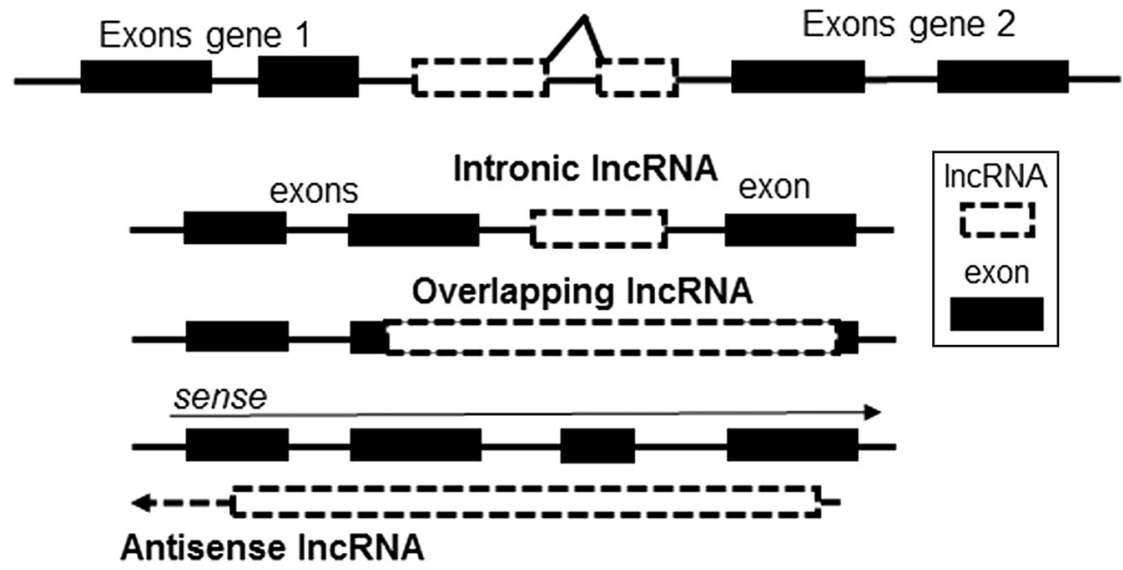

Figure 2

Classification of IncRNAs based on their location and transcription in relation to protein-coding genes. Gene structure is diagramed $5^{\prime}-3^{\prime}$, left to right, for RNA pol II transcription. 


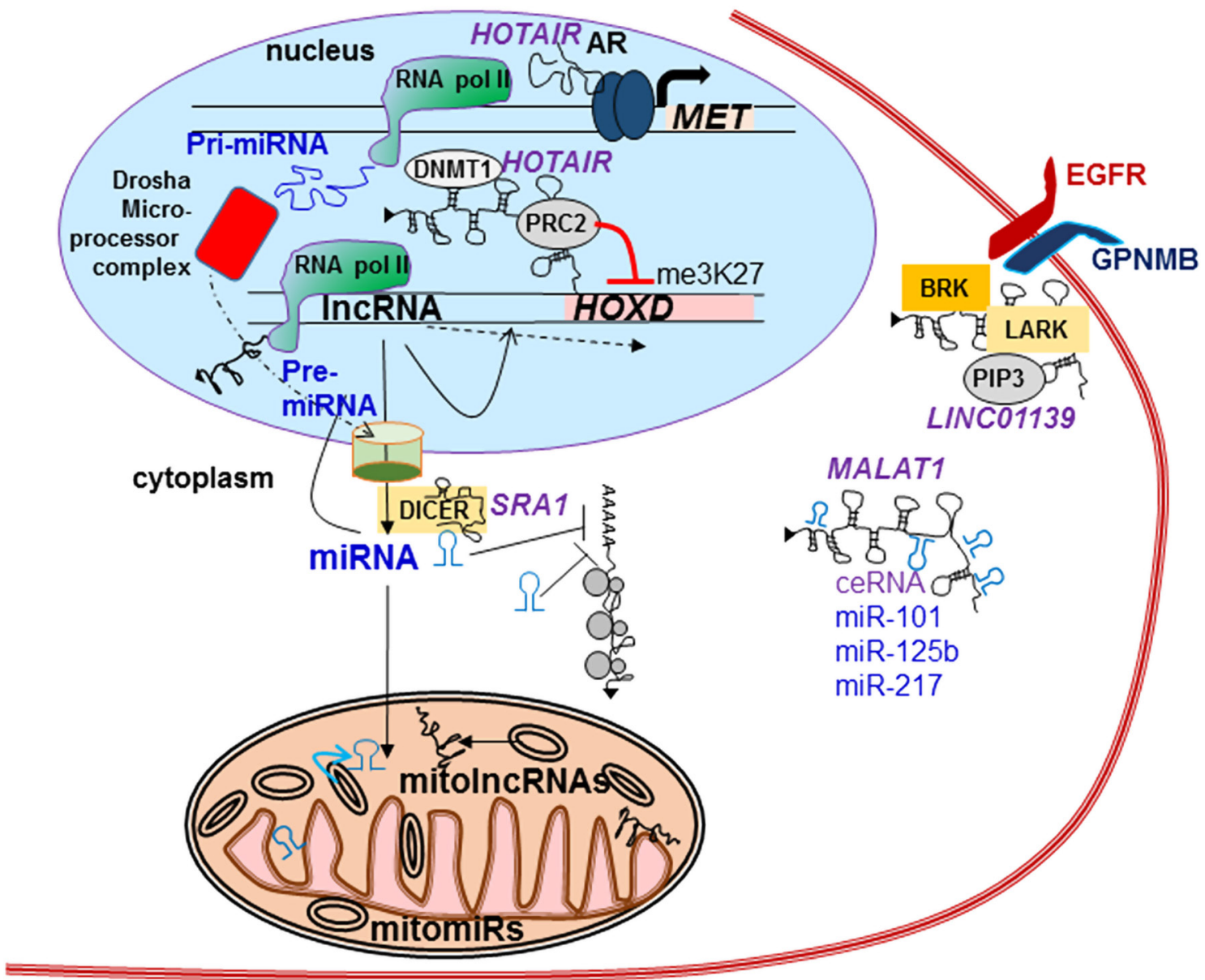

Figure 3

Examples of interactions of IncRNAs and miRNAs in endocrine-related cancers. Not all these interactions may be expected in one cell type. IncRNAs can act in cis on an adjacent gene to regulate its transcription and translation. An example is HOTAIR's interaction with AR (Zhang et al. 2015a). Nuclear miRNAs can be transported into mitochondria through unknown mechanisms and miRNAs are produced from the mtDNA genome (ds DNA plasmids shown), both are called 'mitomiRs'. IncRNAs are transcribed from mtRNA and are called mitolncRNAs. Pri-miRNAs are process to pre-miRNAs by the Drosha microprocessor complex and exported by Exportin/RAN GTPase to the cytoplasm where they are cleaved into mature miRNAs by DICER which interacts with the IncRNA SRA1 (Redfern et al. 2013). LINC01139 acts as a scaffold for PIP3, BRK, LRK2 and GPNMB, which leads to HIF-1 $\alpha$

phosphorylation (Lin et al. 2017). MALAT1 acts as a ceRNA and 'sponges' miRNAs including miR-101, miR-125b and mIR-217 (Table 2 and Supplementary Table 1).

promotes AKT recruitment and phosphorylation (Lin et al. 2017). Several lncRNAs modulate mRNA stability (reviewed in Rashid et al. 2016). IncRNAs also associate with ribonucleoprotein complexes to regulate translation. For example, ZFAS1 associates with the 40S ribosome in the cytoplasm of MDA-MB-468 breast cancer (BCa) cells and is downregulated in breast tumors compared with normal breast tissue (Hansji et al. 2016).

\section{Examples of IncRNAs dysregulated in endocrine-related cancers}

Although many lncRNAs have been identified using bioinformatic approaches, relatively few have been functionally characterized and little is known about the mechanism(s) of action of even the best characterized lncRNAs. This review is not comprehensive with respect to lncRNAs in endocrine-related cancers, but summarizes representative IncRNAs that are best characterized (Table 2 and described below). Examples of recent reviews of lncRNAs include roles in: female reproductive cancers (Ong et al. 2017), BCa (Malih et al. 2015, Venkatesh et al. 2015, Miano et al. 2016, Niknafs et al. 2016, Warburton \& Boone 2017), prostate cancer (PCa) (Alahari et al. 2016, Zhang et al. 2016a,c, Yang et al. 2017b) and thyroid cancer (Murugan et al. 2017).

One of the first characterized lncRNAs, HOTAIR (HOX Transcript Antisense RNA) is a $2.2 \mathrm{~kb}$ lncRNA 
found only in mammals and its structure is conserved, despite changed sequences, especially in its proteinbinding segments, implying evolutionary importance (Jarroux et al. 2017). HOTAIR is transcribed from the HOXC locus from a position intergenic and antisense to the flanking HOXC11 and HOXC12 genes. HOTAIR facilitates the HOXD gene cluster for transcriptional repression by recruiting PRC2 (Rinn et al. 2007). Analysis of data in the Cancer Genome Atlas (TCGA) revealed that increased HOTAIR expression correlates with metastasis and poor prognosis in breast and prostate cancers (Weidle et al. 2017). HOTAIR is both nuclear and cytoplasmic and considered an onco-lncRNA because of its ability to promote papillary thyroid cancer (PTC) cell proliferation and silencing its expression inhibited cell growth (Zhu et al. 2016). HOTAIR is a scaffold for the PRC2 and LSD1 complexes affecting H3K27 methylation and H3K4 demethylation for epigenetic gene silencing promoting cancer metastasis (Wu et al. 2014). HOTAIR decreases oxidative phosphorylation (OXPHOS) complex III subunit VII (UQCRQ) protein expression, thus reducing OXPHOS efficiency and suggesting that HOTAIR is important for mitochondrial function in HeLa cells (Zheng et al. 2015).
According to Gene Cards (www.genecards.org), HOTAIR has binding sites for 70 proteins involved in transcriptional regulation including AGO1, SIN3A, REST, SUZ12, RELA, ROSL1, MAX, MAZ, NR2C2 (orphan NR TR4), TBP, EGR2, ELK4 and SP2. HOTAIR is upregulated by HIF-1 $\alpha$, histone methylase MLL1 and coactivator p300 (Bhan et al. 2017). HOTAIR was reported to be induced by $\mathrm{E}_{2}$ in MCF-7 BCa cells (Bhan et al. 2013), but others reported that $\mathrm{E}_{2}-\mathrm{ER} \alpha$ directly that repressed HOTAIR in MCF-7 cells by binding to a genomic site $14.5 \mathrm{~kb}$ upstream of HOTAIR (Xue et al. 2016b). HOTAIR is downregulated by miR-141 (Chiyomaru et al. 2014) and is directly targeted by miR-34a in PCa cells (Chiyomaru et al. 2013). The 3' domain of HOTAIR binds lysine-specific demethylase 1 (LSD1)-CoREST and PRC2 interacts with a $5^{\prime}$ domain. HOTAIR-PRC2 interaction represses targets, e.g., HOXD10, PTEN, miR-7 and WIF1, which leads to the activation of the Wnt/ $\beta$-catenin signaling pathway (Hajjari \& Salavaty 2015). HOTAIR binds androgen receptor (AR), blocking MDM2 interaction, and preventing AR ubiquitination and protein degradation, thus contributing to castrationresistant prostate cancer (CRPCa) progression (Zhang et al. 2015). HOTAIR is upregulated in endocrine-resistant BCa cells and its overexpression activates ER $\alpha$ transcriptional

Table 2 Examples of the roles of selected IncRNAs identified in endocrine-related cancers. Name, size, and genome location information is summarized from the sources for IncRNAs in Table 1. Other information is from the references cited.

\begin{tabular}{|c|c|c|}
\hline $\begin{array}{l}\text { IncRNA } \\
\text { gene }\end{array}$ & Name, size, location & Interactions \\
\hline PCA3 & $\begin{array}{l}\text { Prostate cancer- } \\
\text { associated } 3 \\
23,134 \mathrm{nt} \\
9 \mathrm{q} 21.2 \\
\text { Antisense lincRNA } \\
\text { within PRUNE2 }\end{array}$ & $\begin{array}{l}\text { PCA3 and PRUNE2 pre-mRNA are } \\
\text { co-expressed and form a double- } \\
\text { stranded RNA that recruits adenosine } \\
\text { deaminase acting on RNA (ADAR) } \\
\text { proteins to form a complex (Zhang } \\
\text { et al. } 2016 a, c)\end{array}$ \\
\hline
\end{tabular}

GAS5 Growth arrest specific 5 Forms hairpin structures and interacts $1 \mathrm{q} 25.1$

The GAS5 gene has 12 exons that are alternatively spliced into 2 mature IncRNAs Represses onco-miR-21 (Zhang et al. and GAS5 introns encode 10 snoRNAs (reviewed in Pickard \& Williams 2014) Tumor suppressor

MEG3 Maternally expressed 3 $14 q 32.2$

$81,622 \mathrm{nt}$

Tumor suppressor

\begin{tabular}{l} 
Regulation \\
\hline Increased by \\
androgens in \\
prostate \\
cancer cells \\
(Salameh et al. \\
2015 ) \\
Suppressed by \\
ER $\beta$ (Zhang \\
et al. 2016a,c)
\end{tabular}
with the DNA binding domain of GR to inhibit GR-GRE binding and GR-induced gene transcription (Kino et al. 2010) 2013) Inhibited miR-103 in EC cells (Guo et al. 2015)

Inhibited activation of the AKT/mTOR pathway in PC3 PCa cells (Xue et al. 2016a)

Binds miR-421 (Zhang et al. 2017c,e) Co-immunoprecipitates with PI3K in HEC-1B EC cells (Sun et al. 2017a)

\section{Endocrine cancer \\ PCa-specific urine biomarker (Laxman et al. 2008); levels inversely correlate with the tumor suppressor PRUNE2 in human PCa specimens (Salameh et al. 2015) \\ Low expression correlated with poor prognosis in thyroid cancer tissues (Guo et al. 2017); low expression in breast tumors from trastuzumab-treated patient (Li et al. 2016b) \\ Lower in PCa tissues than normal prostate (Xue et al. 2016a)}

Downregulated in breast (Zhang et al. 2016a,c, 2017c,e), prostate (Zhang et al. 2016a,c), endometrial (Guo et al. 2016b, Sun et al. 2017a), and PTC (Murugan et al. 2017) tumors 
activity independent of ligand (Xue et al. 2016a). ERo interacts directly of HOTAIR in RNA pulldown assays using nuclear extracts from MCF-7 BCa cells (Xue et al. 2017). Overexpression of HOTAIR in MCF-7 cells grown under hormone-free (serum-starved) medium conditions increases the number of DNA sites to which ERo binds in chromatin immunoprecipitation assays (ChIP) and increases mRNA expression of some ER $\alpha$ target genes, e.g., GREB1, TFF1, PGR and CTSD (Xue et al. 2016b). The authors concluded that HOTAIR increases ligand-independent ER $\alpha$ transcription. This observation is concordant with a report of increased HOTAIR immunostaining in tamoxifenresistant human breast tumors (Xue et al. 2016b).

In contrast, HOTAIR was not among the 20 lncRNAs identified as upregulated and 9 downregulated by 'apo-ER $\alpha$ ' (non-ligand-occupied ER $\alpha$ ) in a bioinformatic analysis of BCa cell lines and tumor tissues with experimental follow-up in MCF-7 cells (Miano et al. 2016). That study identified DSCAM-AS1 as the most apo-ER $\alpha$-upregulated IncRNA and its expression was higher in luminal $\mathrm{A}$ and $\mathrm{B}$ breast tumors compared to normal breast, HER2+ or basal-like tumors. Knockdown of DSCAM-AS1 stimulated an increase in epithelial-tomesenchymal (EMT) markers in MCF-7 cells. DSCAM-AS1 was also upregulated in prostate and lung tumors (Miano et al. 2016). A bioinformatics interrogation of 947 breast tumor RNA-seq libraries identified gene sets positively correlated with DSCAM-AS1 expression as significantly associated with clinical signatures of cancer aggression, tamoxifen resistance, higher grade, stage and metastasis (Niknafs et al. 2016).

HOTAIR interacts with ER $\beta$ in a complex with eNOS on gene promoters to stimulate transcription in $\mathrm{LNCaP} \mathrm{PCa}$ cells and a primary prostate tumor-derived cell line (called C27IM) and with ER $\alpha /$ eNOS in MCF-7 cells (Aiello et al. 2016). A potential concern with regard to the conclusion of the ChIPping of ER $\beta$ is the notorious lack of specificity of ER $\beta$ antibodies (Andersson et al. 2017, Nelson et al. 2017). HOTAIR is upregulated in endometrial cancer (EC) (Smolle et al. 2015) and contributes to cisplatin resistance by inhibiting autophagy (Sun et al. 2017b). HOTAIR is highly expressed in ovarian cancer (Luo et al. 2017); endometrial, ovarian and cervical cancers (Li et al. 2017a) and thyroid cancers (Zhang et al. 2017c,e), including PTC (Zhu et al. 2016).

MALAT1 (metastasis-associated lung adenocarcinoma transcript 1, $8755 \mathrm{nt}$ ) is another well-studied lncRNAs with roles in endocrine-related cancers (reviewed in Zhang et al. 2017d). MALAT1 is expressed in almost all human tissues and is conserved across 33 mammalian species
(Jarroux et al. 2017). MALAT1 lacks a poly A tail, but has a genomically encoded poly $\mathrm{A}$ tract and is processed into a $6.7 \mathrm{~kb}$ nuclear form and a smaller MALAT1-associated small cytoplasmic RNA (mascRNA) (Zhang et al. 2017d). MALAT1 is $\mathrm{m}^{6} \mathrm{~A}$ modified on 4 of 7 sites located in hairpins of MALAT1 within HeLa, HEK-293T and MDA-MB-231 cells (Liu et al. 2013). Others reported that $\mathrm{m}^{6} \mathrm{~A}$ on position 2577 of MALAT1 alter its secondary structure, enhancing its interaction with the $\mathrm{m}^{6} \mathrm{~A}$ reader heterogeneous nuclear ribonucleoprotein C (HNRNPC) (Zhou et al. 2016). The DROSHA-DGCR8 microprocessor associates with the 5' end of MALAT1. MALAT1 acts as a sponge for nuclear miR-9 and cytoplasmic miR-133, miR-200s and miR-205, although the exact mechanisms of how MALAT1 gets to the cytoplasm are unclear (Zhang et al. 2017d). In turn, MALAT1 is post-transcriptionally downregulated by miR-101, miR-125b and miR-217. The crystal structure of MALAT1 revealed it to be a triple helix RNA that is stable in cells, e.g., $t_{1 / 2}$ of $7 \mathrm{~h}$ in HeLa cells (Brown et al. 2014). Functionally, nuclear speckle-associated MALAT1 is involved in alternative splicing by acting as a scaffold (Tripathi et al. 2010). MALAT1 is considered oncogenic and it upregulates the Wnt/ $\beta$-catenin pathway (Ong et al. 2017). Capture hybridization analysis of RNA targets (CHART) identified MALAT1 genomic-binding sites to be at actively transcribed loci (reviewed in Zhang et al. 2017d). However, Malat1-knockout (ko) mice showed no obvious phenotype, were viable and fertile and showed correct localization of nuclear speckles (Nakagawa et al. 2012). Expression of the IncRNA Neat1, which is located $30 \mathrm{~kb}$ upstream ( $5^{\prime}$ ) to Malat1, was lower in Malat1 ko mice, suggesting a role for Malat1 as a cis-regulator of Neat1. RNA-seq studies in adult Malat1 ko mice revealed upregulation of a small number of adjacent genes, also suggesting cis regulation (Zhang et al. 2012). One explanation for the lack of concordance between cellular and whole mouse studies is that Malat1 may only function under stress conditions (reviewed in Zhang et al. 2017d). Increased MALAT1 is found in many cancers including breast tumors (Ellis et al. 2012), castration-resistant prostate (Ren et al. 2013, Wang et al. 2014, Sowalsky et al. 2015), EEC (Zhao et al. 2014), recurrent ovarian cancer (Yang et al. 2017b) and thyroid tumors (Zhang et al. $2017 a, b)$. Studies suggest that increased MALAT1 plays a role in metastasis (reviewed in Zhang et al. 2017d). MALAT1 mutations are frequent in breast tumors (Arun et al. 2016, Nik-Zainal et al. 2016). MALAT1 expression was higher in thyroid cancer tissues and in thyroid cancer cells than normal thyroid (Huang et al. 2016a). Likewise, NEAT1 is upregulated in breast (Qian et al. 
2017), endometrial (Wang et al. 2017a,c), ovarian (Chen et al. 2016) and thyroid tumors (Li et al. 2017b) and is the highest lncRNA in prostate cancer and strongly associated with metastasis (Chakravarty et al. 2014).

lincRNA-p21 (gene name TP53COR1) is a transcript of $\sim 3 \mathrm{~kb}$ that is increased by p53 in response to DNA damage and serves as a transcriptional repressor in the p53 pathway by directly interacting with HNRNPK (hnRNP-K), increasing p21 transcription and inhibiting the transcription of pro-survival genes, thus triggering apoptosis (Barsotti \& Prives 2010, Dimitrova et al. 2014). lincRNA-p21 is increased by hypoxia via HIF- $1 \alpha$ and interacts with and stabilizes HIF- $1 \alpha$, resulting in increased glycolysis in HeLa cells (Yang et al. 2014). lincRNA-p21 is degraded by let-7 (Yoon et al. 2014). lincRNA-p21 is transcribed into two isoforms with Alu inverted repeat elements and colocalizes with the IncRNA NEAT1 in the nucleus of U2OS, HCT-116 and MCF-7 cells (Chillón \& Pyle 2016). lincRNA-p21 represses the translation of specific target genes, including CTNNB1 ( $\beta$-catenin), through RISC complex activation. Knockdown of heatshock factor 1 (HSF1) in MDA-MB-231 cells increased lincRNA-p21 expression and the authors identified miR-320a, b and c as dependent on HSF1 that may target lincRNA-p21 through its $5^{\prime}$ sequence, although this was not demonstrated (Chou et al. 2015). lincRNA-21 is downregulated in PCa and acts as a tumor suppressor in $\mathrm{PCa}$ cells (Wang et al. 2017a,c). Overexpression of lincRNA-p21 in DU145 and LNCaP PCa cells decreased pyruvate kinase M2 (PKM2) expression in a PTEN/AKT/mTOR cascade-dependent manner and transfection with shlincRNAP21 reduced glucose consumption (Wang et al. $2017 b, d)$. There are no reports on IncRNA-21/TP53COR1 in either endometrial or thyroid cancer.

\section{IncRNAs in breast tumors}

A recent review of the function of selected lncRNAs upregulated (19) and downregulated (5) in BCa noted that while thousands of dysregulated IncRNAs have been identified, about most relatively little is known (Warburton $\&$ Boone 2017). Bioinformatic reanalysis of RNA-seq data from 658 invasive ductal carcinomas from TCGA and sorted by PAM50 assay transcriptomic data identified 1623 lncRNAs expressed at FPKM (fragments per kilobase of non-overlapped exon per million fragments mapped) $>1$ in $10 \%$ of the tumors that the authors postulated are relevant in BCa (Su et al. 2014). IncRNA-based unsupervised hierarchical consensus clustering revealed four subgroups that correlated with mRNA transcriptome
PAM50 classification: basal-like, HER2-enriched and luminal A and B. Clustering suggested that HOTAIR was higher in HER2-enriched breast tumors. ACC005152.3, RP11-84E24.2 and HOTAIRM1 were higher in basal-like breast tumors, whereas RP11-53019.2 and RP11-473L15.3 were higher in luminal-type tumors. Su and coworkers correlated increases in lncRNAs with increased adjacent gene expression: HOTAIR with HOXC11; HOTAIRM1 with HOXAI; RP11-53O19.2 and RP11-473L15.3 with MRPS30 and ACC005152.3 and RP11-84E24.2 with SOX9 (Su et al. 2014). HOTAIRM1 SOX9 is a stem cell factor involved in tamoxifen-resistant BCa (Jeselsohn et al. 2017). HOTAIR and BCL2 expression were correlated in breast tumors and HOTAIR was shown to act as a ceRNA by base-pairing with miR-206, thus relieving mIR-206's repression of BCL2 expression (Ding et al. 2017). HOTAIRM1 expression increased in recurrent ovarian cancer (Yang et al. 2017b), but acts as a tumor suppressor in colorectal cancer (Wan et al. 2016).

Another group performed a similar analysis on RNAseq data in the TCGA using 1000 breast tumors, an independent RNA-seq dataset of 50 pairs of matched tumors and adjacent normal tissues from BCa patients, and 23 normal breast tissues from healthy women (Zhang et al. 2016b,d). They identified 2171 lincRNAs expressed in at least one sample, often at low levels, and ultimately identified 83 differentially expressed lincRNAs of which 60 were downregulated in breast tumor samples. Among the upregulated lincRNAs, GATA-AS1 was associated with higher expression of its adjacent protein-coding gene GATA3 and both were associated with ER $\alpha+$ breast cancer. GATA3 regulates the transcription of genes involved in maintaining luminal mammary gland differentiation (Kouros-Mehr et al. 2006) and acts as a licensing factor for $\mathrm{ER} \alpha$-chromatin binding (Theodorou et al. 2013). GATA-AS1 may be unique in $\mathrm{BCa}$ since no reports were found for the other endocrine cancers discussed in this review. One upregulated lincRNA RP5-1198O20 was associated with lower survival rates in BCa patients (Zhang et al. $2016 b, d)$. How RP5-1198O20 contributes to BCa mortality is currently unknown.

ANRIL was identified as the IncRNA with the highest expression in SK-BR3 HER2+ BCa cells vs MCF-10A cells in a lncRNA array qPCR study (Lee et al. 2017). ANRIL expression was also higher in MCF-7 and T47D cells compared with MCF-10A cells. Some IncRNAs are associated with specific metastasis, e.g., lnc-BM (OR5BM1P) for BCa brain metastasis by interacting with JAK2 to activate a STAT3-ICAM1 axis that increases cell adhesion to brain capillaries and extravasation (Wang et al. 2017b,d). 
XIST is best known for $\mathrm{X}$ chromosome inactivation (da Rocha \& Heard 2017). However, XIST interacts on a genome-wide scale with a variety of proteins, including the scaffold attachment factor A (SAF-A), in the nonchromatin nuclear scaffold/matrix (Creamer \& Lawrence 2017). XIST is downregulated in breast tumors, but its molecular mechanisms as a tumor suppressor are unclear (Huang et al. 2016b). One idea is that loss of XIST induces reactivation of X-linked genes that contribute to $\mathrm{BCa}$ progression (Chaligne et al. 2015). However, XIST's role as a tumor suppressor may depend on the type of breast tumor. Patients with high XIST mRNA and low protein expression of 53BP1 in BRCA1-like breast tumors showed no benefit from high-dose alkylating chemotherapy and lower disease-free and overall survival (Schouten et al. 2016). XIST expression was also decreased in uterine papillary serous carcinoma accompanied by widespread $X$ chromosome demethylation (Zhang et al. 2014). There are no apparent functional studies of XIST in EC cells.

New IncRNAs continue to be discovered. A recent example is ESRP2-AS that was first identified in a methylated lncRNA screen in a transgenic mouse model of human BCa (C3(1) SV40Tag) and shown to be higher in human breast tumors compared to normal breast tissue (Heilmann et al. 2017). Additional lncRNAs identified in BCa are included in Table 2.

\section{IncRNAs in prostate tumors}

Most IncRNAs identified in PCa are upregulated, thus acting as oncogenes (reviewed in Zhang et al. 2016a,c). Upregulated IncRNAs include HOTAIR, PCGEM1, PRNCR1, ANRIL, PCAT1, MALAT1 and specific for PCa $P C A 3$. Downregulated IncRNAs in PCa include GAS5, PTENP1 and MEG3. Refer Table 2 for details on PCA3, GAS5 and MEG3. MEG3 modulates the activity of TGF- $\beta$ genes by binding to distal regulatory elements forming an RNA-DNA triplex and interacts with the PRC2 complex (Mondal et al. 2015).PCAT1 is the most highly upregulated lncRNA in PCa (Alahari et al. 2016). Mechanistically PCAT1 post-transcriptionally represses tumor suppressor gene $B R C A 2$, thus impairing homologous recombination DNA repair. Overexpression of PCAT1 in DU145 PCa cells increased proliferation, migration, and invasion and post-transcriptionally upregulated MYC by interacting with miR-3667-3p (Prensner et al. 2014). Another study showed interaction between PCAT1 and miR-145-5p that resulted in upregulation of FSCN1, an actinbinding protein involved in invasion and migration (Xu et al. 2017). Overall, PCAT1 has an oncogenic role in PCa (Alahari et al. 2016). Interestingly, a PCa risk SNP (rs7463708) promotes transformation via upregulation of PCAT1 lncRNA (Guo et al. 2016a). PCAT1 is also upregulated in hepatocellular carcinoma (HCC) (Zhang et al. 2017a,b). Additional lncRNAs in PCa are included in Table 2.

\section{IncRNAs in EC}

The death rate for cancer of the uterine corpus, which is associated with obesity, is increasing in the U.S. (Siegel et al. 2017). EC is classified as type I or II with most patients having well-differentiated endometrioid endometrial carcinomas (EEC, type I) (Takenaka et al. 2016). The identity and characteristics of IncRNAs dysregulated in EEC, including MALAT1, HOTAIR, SRA, H19, OVAAL, RP11395G12.3, LA16313D11.11, CASC2, ASLNC04080 and ENSTO000050294 were reviewed (Takenaka et al. 2016). The roles and functions of selected IncRNAs, i.e., MALAT1, HOTAIR, H19, MEG2, CCA2, ANRIL, OCAL, $B C 2200$ and CUDR in cancers of the female reproductive system including endometrial, ovarian and cervical cancers were recently reviewed (Hosseini et al. 2017). H19 is a well-studied imprinted, maternally expressed lncRNA that encodes miR-675 and is overexpressed in breast, HCC, prostate, colorectal, esophageal, bladder and many other cancers but is downregulated in adrenocortical neoplasms (reviewed in Huarte 2015).

\section{IncRNAs in thyroid cancer}

The role of IncRNAs in the pathogenesis of thyroid cancer was recently reviewed (Murugan et al. 2017). PTC is the most common thyroid malignancy (Siegel et al. 2017). A microarray analysis of lncRNAs in 62 PTC tumors identified 3499 IncRNAs (1192 upregulated, 2307 downregulated) that were differentially expressed compared with paired noncancerous tissue (Lan et al. 2015). qPCR confirmed the 'direction' of lncRNA expression in PTC: TCONS_12_00010365, n386477, n340790, lnc-LLPH-2:1 and NR_003225.2 were upregulated and lnc-PSD4-1:14, n335550, lncKCMF1-2:1, lnc-PLA2R1-1:1 and ENST00000422494.1 were downregulated (Lan et al. 2015). As indicated in Table 2, MALAT1 is upregulated in thyroid tumors (Zhang et al. 2017a,b). MALAT1 is also upregulated in SW1736, KAT18 and FTC133 thyroid cancer cells and knockdown of MALAT1 inhibited cell proliferation and invasion by upregulating the expression of the scaffolding protein IQGAP1 (Huang et al. 2016a). 


\section{Mitochondrial-encoded IncRNAs and IncRNA imported into mitochondria}

The human mitochondrial DNA (mtDNA) genome is transcribed as a polycistronic precursor and encodes 13 proteins that function in mt OXPHOS, two rRNAs that are components of the mt ribosome and 22 tRNA (Kim et al. $2017 b$ ). Seven IncRNAs have been identified to be derived from mtDNA (De Paepe et al. 2017). These are referred to as mitolncRNAs (Vendramin et al. 2017). Several are chimeric lncRNAs containing nucleotides of mtDNA: LIPCAR, SncmtRNA, ASncmtRNA-1 and ASncmtRNA-2. LIPCAR is cardiac specific and levels are elevated in circulation of patients with chronic heart failure (Kumarswamy et al. 2014). ASncmtRNA-1 and ASncmtRNA-2 are present in mitochondria and nuclei, suggesting a possible role in retrograde signaling (De Paepe et al. 2017). ASncmtRNA-1 and ASncmtRNA-2 are downregulated in breast and prostate tumors (Burzio et al. 2009), suggesting tumor suppressor activity. However, complete knockdown of ASncmtRNA-1 and ASncmtRNA-2 stimulated apoptotic cell death by downregulating the translation of survivin, an anti-apoptotic protein, only in cancer cells through an undefined mechanism, although these lncRNAs were shown to interact with DICER (Vidaurre et al. 2014). To date, the mechanism of ASncmtRNA-1 and ASncmtRNA-2 remains unknown (De Paepe et al. 2017, Dong et al. 2017). Three lncRNAs: ncND5, lncND6 and lncCyt b were identified as antisense transcripts of the mtND5, mtND6 and mtCYTB mRNAs but little is known about their function (Rackham et al. 2011). There is speculation that these three lncRNAs are transported to the nucleus by unknown RNA-binding proteins (Dong et al. 2017). Recently, two novel IncRNAs MDL1 and MDL1AS encoded in the D-loop of human mitochondrial DNA were discovered and identical transcripts were identified in mouse and rat genomes (Gao et al. 2017).

RMRP (RNA Component Of Mitochondrial RNAProcessing Endoribonuclease) is a nuclear DNA-encoded lncRNA that binds RNA-binding proteins HUR, PNPASE and GRSF1 for transport into mitochondria where RMRP is the RNA component of the mitochondrial RNAprocessing endoribonuclease (RNase MRP) for mtDNA replication and RNA processing (Dong et al. 2017). RMRP acts as a sponge for miR-206 an oncogene in lung cancer (Meng et al. 2016). Deep sequencing of 360 primary breast tumors identified mutations in the promoters of lncRNAs RMRP and NEAT1 that increased their expression and noted increased expression of these lncRNAs in breast tumors (Rheinbay et al. 2017). However, RMRP's role in
BCa remains to be fully elucidated, and no publications were found with respect to $R M R P$ in prostate, endometrial, ovarian or thyroid cancer.

SRA1, steroid receptor RNA activator, was first identified as an RNA transcript acting as an RNA coactivator in a complex with SRC-1 (NCOA1) to increase progesterone, glucocorticoid, androgen, estrogen, thyroid hormone, retinoic acid and peroxisome proliferator-activated receptor (PR, GR, AR, ER $\alpha, \mathrm{TR} \beta, \mathrm{RAR} \gamma, \mathrm{RXR} \gamma$ and PPAR $\gamma$ ) transcriptional activity (Lanz et al. 1999). Knockout of Sra1 in mice showed that the Sra-/- mice were resistant to high-fat diet-induced obesity and had lower fat mass (Liu et al. 2014). In humans, inactivating SRA1 mutations were identified in three families with a proband with idiopathic hypogonadotropic hypogonadism (Kotan et al. 2016). The SRA1 gene also encodes a protein steroid receptor coactivator protein (SRAP) (reviewed in Leygue 2007) that interacts with $\mathrm{AR}$ and is involved in $\mathrm{PCa}$ (Kawashima et al. 2003). Notably, SRA1 and SRAP do not interact (McKay et al. 2014). SRA1's identity as a lncRNA was revealed in 2012 (Novikova et al. 2012). Additional protein-binding partners of $S R A 1$ were recently reviewed (Liu et al. 2016). SRA1 interacts with DICER (Redfern et al. 2013). By its interaction with SLIRP (SRA stem-loop interacting RNA-binding protein), SRA1 has a repressive function by recruiting corepressors (reviewed in Liu et al. 2016). SLIRP represses NR transactivation in an SRA1-dependent manner (Hatchell et al. 2006). Interestingly, Slirp-knockout mice are sub-fertile, and males have defects in sperm motility and mitochondrial morphology (Colley et al. 2013). SRA1 and SLIRP were identified as a BCL2-interacting RNA and proteins, respectively in mitochondria of H1299 lung adenocarcinoma cells (Trisciuoglio et al. 2016). The SMRT/HDAC1 corepressor complex interacts with SRA1 (Dong et al. 2017). SRA1 is upregulated in steroid hormoneresponsive tumors including breast, endometrial and ovarian (reviewed in Liu et al. 2016).

\section{IncRNAs in circulation}

Circulating nucleic acids, including miRNAs and lncRNAs, are found in cell-free serum, plasma and other bodily fluids and differ between cancer patients, including those with prostate and breast tumors and non-cancer/normal individuals (reviewed in Qi et al. 2016). In addition, virtually all cells release membrane-enclosed extracellular vesicles (EV): exosomes $(0.04-0.15 \mu \mathrm{m}$ diameter) and microvesicles $(0.2-1 \mu \mathrm{m}$ diameter); further, apoptotic 
cells release apoptotic bodies $(0.5-2 \mu \mathrm{m}$ diameter $)$ that do not contain miRNAs and lncRNAs (Kim et al. 2017a). Exosomes, which arise from the endosomal pathway, and microvesicles have been reported to transport mRNAs, ncRNAs, including miRNAs, IncRNAs and circRNAs, as a mechanism of intercellular communication (Kim et al. 2017a). Cancer exosomes modulate the immune response and the tumor environment locally and at a distance, i.e., metastasis to secondary sites, by horizontal cargo transfer to recipient cells (Ruivo et al. 2017). In a recent study, isolated exosomes from tamoxifen-resistant LCC2 BCa cells were shown to contain $\sim 25$-fold higher lncRNA UCA1 compared to parental MCF-7 cells and incubation of MCF-7 cells with exosomes from LCC2 cells resulted in decreased growth inhibition by tamoxifen (Xu et al. 2016), although no uptake of UCA1 or other IncRNAs or miRNAs was examined. There is great interest in EVs as biomarkers and as tools to deliver therapeutic genetic materials and drugs. Interestingly, a recent study reported that EVs isolated from $\mathrm{BCa}$ patients with metastatic disease and whose initial tumor had been $\mathrm{ER} \alpha+/ \mathrm{PR}+/ \mathrm{HER} 2-$ contained mtRNA from cancer-associated fibroblasts (CAFs) (Sansone et al. 2017). Xenograft transplantation studies in immunocompromised mice demonstrated that transfer of mtDNA from CAFs contributed to resistance to fulvestrant in vivo. Whether accompanying miRNAs and IncRNAs play a role in these findings was not evaluated.

\section{IncRNA therapeutics}

Antisense oligonucleotides (ASO), liposome-delivered RNAi, vector-expressed shRNAs and decoy RNAs or small molecules that compete for domain-domain interactions between lncRNA and proteins or within the IncRNA are of interest in targeting overexpressed lncRNAs in cancer (Weidle et al. 2017). Targeting of lncRNAs using lncRNAs and nanoparticle-coated siRNAs has been successful in preclinical mouse models of BCa (Liu et al. 2015, Wang et al. 2017b,d). Approximately 25 RNAi-based therapeutics are under clinical investigation (Weidle et al. 2017).

\section{Overview of miRNA biosynthesis in endocrine-related cancers}

miRNAs are small (22 nucleotides), evolutionarily conserved, single-stranded, ncRNAs that regulate mRNA translation or stability by base-pairing with miRNA response elements (MREs) in the 3'UTR of the target transcript within the RNA-induced silencing complex (RISC). The chronology of miRNA discovery was recently reviewed (Drusco \& Croce 2017). Comparative genomics analysis indicated that $>60 \%$ of human protein-coding genes have been under selective pressure to maintain pairing to miRNAs with $>45,000$ miRNA-binding sites within 3 'UTRs conserved (Friedman et al. 2009). The human genome includes 2,588 mature miRNAs (mirBase release 21) http://www.mirbase.org/ (Kozomara \& Griffiths-Jones 2014).

The biogenesis of miRNAs has been reviewed (Ha \& Kim 2014, Klinge 2015). In brief, in the canonical pathway of miRNA biogenesis, miRNAs are transcribed as primary-micro-RNAs (pri-miRNAs) by RNA pol II either as independent transcription units or are cotranscribed within introns of pre-mRNAs ( $50 \%$ of miRNAs) (Saini et al. 2007). Most pri-miRNAs are $>1 \mathrm{~kb}$, thus meeting the definition of a lncRNA (Dykes \& Emanueli 2017). About half of all miRNAs are produced from non-coding transcripts, i.e., host lncRNAs. One example is DLEU2 that encodes the miR-15a/16.1 cluster and MIR155HG that encodes miR-155 (reviewed in Dykes \& Emanueli 2017). Pri-miRs are capped and polyadenylated (Cai et al. 2004). The microprocessor complex of DROSHA (an RNAse III endonuclease) and DGCR8, plus additional proteins, cleaves hairpin-loop-containing pri-miR into 60-70 nucleotide (nt) precursor (pre)-miRNAs. The efficiency of pri-miRNA processing depends on stem length ( $36 \pm 3 \mathrm{nt})$ and the appearance of bulges in the structure (Roden et al. 2017). DGCR8 acts as an oncogene in prostate cancer whereas DROSHA has oncogenic or tumor suppressor activity depending on the cancer type (reviewed in Hata \& Kashima 2016). Alternative pathways of miRNA biogenesis include miRtrons, which are processed by spliceosomes in a DROSHA/DGCR8-independent/DICER-dependent manner and DROSHA/DGCR8-dependent/DICERindependent yielding miR-451 (reviewed in Daugaard \& Hansen 2017). The widespread reduction of miRNAs in human tumors has been attributed to dysregulation of the DROSHA/DGCR8 microprocessor complex as a result of the many pathways that regulate microprocessor components, e.g., p72 is sequestered by YAP in the Hippo pathway in a cell-density-dependent manner (Mori et al. 2014). RNA-binding proteins also regulate pri-miRNA accessibility (Fernandez et al. 2017).

Pre-miRNAs are exported from the nucleus by Exportin and Ran-GTP or CRM1 to the cytoplasm where they are cleaved by DICER (DICER1, an RNAse III enzyme) forming 21-23 nt transiently double-stranded miRNA duplexes (Kurzynska-Kokorniak et al. 2015). DICER, in association with cofactors TRBP and PACT, transfer the mature miRNA to RISC, which contains the catalytic argonaute proteins 
(AGO1, AGO2, AGO3 and AGO4) (Hock \& Meister 2008)) that unwind the mIRNA duplexes to form single-stranded miRNAs. The IncRNA SRA1 binds DICER complex components PACT, TRBP and PKR in various cell lines and also binds NRs, including ER $\alpha$ (Redfern et al. 2013). DICER also plays a role in the DNA damage response in which DNA damage results in phosphorylation and binding to double-strand breaks and recruits DNA repair factor MDC1 and 53BP1 (Burger et al. 2017). DICER acts as an oncogene in PCa but as a tumor suppressor in breast, endometrial and ovarian cancer (reviewed in Hata \& Kashima 2016). DICER is regulated transcriptionally, posttranscriptionally, including by alternative splicing, and by post-translational modifications, e.g. phosphorylation, glycosylation and SUMOylation (Kurzynska-Kokorniak et al. 2015). Germline DICER1 mutations, DICER1 syndrome, were identified as causative in differentiated thyroid cancer and multinodular goiter (de Kock et al. 2014, Rutter et al. 2016, Khan et al. 2017).

In cancer tissues, overexpressed miRNAs that act as oncogenes are referred to as oncomiRs while downregulated miRNAs are called tumor suppressor miRs with their targets, tumor suppressors and oncogenes, respectively dysregulated. However, as we learn more about miRNAs, it is clear that generalization about a particular miRNA being oncogenic or a tumor suppressor depends on cellular context. miRNAs are involved in the post-transcriptional regulation of genes involved in EMT, stemness, cell signaling pathways and regulation of the tumor microenvironment, including the conversion of normal fibroblasts into cancer-associated fibroblasts (CAFs) by transfer of exosomal miRNAs from tumor cells (reviewed in Yang et al. 2017a). An issue in the field is the lack of congruence of miRNAs identified for a particular cancer type, e.g., thyroid cancer, even within a subtype, in different studies. This may be attributed to the number of tumor samples examined, tumor heterogeneity, whole tumor RNA isolation vs laser-capture microdissected tumor cells, the technique used to identify the miRNA (microarray, quantitate real-time PCR (qPCR), or NGS/RNA-seq.), the gene normalizer and statistical approaches used. Databases of putative and experimentally verified targets of miRNAs are listed in Table 1.

Despite the large datasets available on miRNAs in endocrine cancer, functional studies are needed for each miRNA and its targets. Functional analysis of overexpression and silencing of individual miRNAs is used to validate the role of deregulated miRNAs in cancer cells in vitro and animal tumor models, including human tumor cell xenografts and patient-derived xenograft
(PDX) in vivo. An essential step to validate the identify of an mRNA target of a miRNA is to clone the 3'-UTR of the mRNA target downstream of a luciferase reporter and then transfect that reporter into a cell line, with an appropriate loading control either in the same plasmid or another cotransfected reporter, with overexpression and knockdown of the putative miRNA regulator. The investigator should detect reduced luciferase reporter activity and mutation of the MRE in the 3'UTR is required confirm direct miRNA-mRNA target regulation, i.e., validating that the mRNA is a bona fide target of that miRNA. Further validation steps include Western blot to demonstrate decrease target protein expression. Target validation in clinical samples is used to demonstrate disease relevance of the miRNA and its target.

Supplementary Table 1 (see section on supplementary data given at the end of this article) summarizes examples of miRNA dysregulated in $\mathrm{BCa}, \mathrm{PCa}, \mathrm{EC}$ and thyroid cancer with examples of their bona fide, validated, mRNA targets. Cellular functions associated with the miRNA are listed in Supplementary Table 1. In addition, I have added lncRNAs that either downregulate a miRNA or act as ceRNAs, i.e., endogenous sponge for binding a miRNA. It will be clear to the reader that many of the miRNA:IncRNA interactions listed are from non-endocrine cancers and are single reports requiring further validation.

\section{miRNAs in $\mathrm{BCa}$}

In the 12 years since miRNAs were identified to be dysregulated in BCa (Iorio et al. 2005), about 3600 papers have been published in miRNAs in BCa (Fig. 1). There are many recent reviews of the identity, regulation and targets of miRNAs in BCa, e.g., (Egeland et al. 2015, Klinge 2015, Muluhngwi \& Klinge 2015, van Schooneveld et al. 2015, Yahya \& Elsayed 2015, Li et al. 2017c, O'Bryan et al. 2017, Smith et al. 2017). miRNAs regulate key pathways dysregulated in $\mathrm{BCa}$ including apoptosis, cell cycle, cellular energetics, invasion, metabolism and metastasis.

The majority (70\%) of primary breast tumors express $\mathrm{ER} \alpha$, and these patients are treated with endocrine therapies including tamoxifen (TAM); the selective estrogen downregulator (SERD), e.g., fulvestrant and aromatase inhibitors (AI), e.g., anastrozole and letrozole (Ring \& Dowsett 2004, Clarke et al. 2015). Hence, many miRNA studies have examined the correlation of miRNAs with diagnostic markers related to $\mathrm{ER} \alpha$ in $\mathrm{BCa}$, estrogenregulated miRNAs and the potential role of miRNAs in endocrine resistance (Klinge 2015, Muluhngwi \& Klinge 
2015). $\mathrm{ER} \alpha$ is the target of miRNAs including miR-221, miR-222, miR-873, let-7b and let-7i (reviewed in Muluhngwi \& Klinge 2015).

Computational approaches are used to identify putative mRNA and lncRNA targets of miRNAs (Table 2). In addition, specific algorithms to identify possible targets of dysregulated miRNAs in breast tumors and $\mathrm{BCa}$ cell lines have been reported (O’Day \& Lal 2010, Cava et al. 2014, Ru et al. 2015, Liang et al. 2016, Zhang et al. $2016 b, d)$. More recently, various strategies to directly identify miRNA:RNA targets and RNA modifications by protein:RNA immunoprecipitation and high-throughput RNA-seq have been used to examine protein:RNA interactions in human biology, e.g., HITS-CLIP (high-throughput RNA-seq isolated by crosslinking immunoprecipitation) (Darnell 2010); PAR-CLIP (photoactivatable ribonucleoside-enhanced CLIP) (Farazi et al. 2014), iCLIP (crosslinking and immunoprecipitation) (Hong et al. 2015), eCLIP (enhanced CLIP) (Van Nostrand et al. 2016) and dCLIP (denaturing CLIP) (Rosenberg et al. 2017). A downside is that CLIP techniques are technically challenging.

\section{Dysregulation of miRNAs in $\mathrm{PCa}$}

Dysregulation of miRNA expression is correlated with aggressive PCa phenotypes including tumor stage, Gleason grade and disease recurrence (Ren et al. 2014, Cha et al. 2016). Altered miRNA expression is associated with physiological changes in tumorigenesis and disease progression in PCa (reviewed in Chun-Jiao et al. 2017, Vanacore et al. 2017). Changes in miRNA expression contribute to altered expression of genes involved in pathogenesis of metastatic PCa (Kojima et al. 2017). Changes in miRNA expression in PCa have been reviewed and described below.

miRNAs upregulated by AR in PCa include miR-21, miR-27a, miR-32, miR-125b, miR-135a, miR-141 and AR overexpression in PCa downregulates miR-99a (Massillo et al. 2017). miR-125b is the most overexpressed miRNA in PCa and downregulates apoptotic genes including $B A K 1$. A recent review of 104 studies of miRNAs in PCa tissues identified six miRNA consistently upregulated: miR-34a, miR-106b, miR-183, miR-200a/b and miR-301a; and sixteen miRNAs downregulated: miR-1, miR-23b, miR-27b, miR-34b/c, miR-99b, miR-125b, miR-152, miR-187, miR-199a, miR-204, miR-205, miR-224, miR-452, miR-454 and miR-505 (Chun-Jiao et al. 2017). Other oncomiRs overexpressed in PCa are miR-21, miR-32,
miR-221, miR-222, miR-181, miR-18a and miR-429 (reviewed in Kanwal et al. 2017). 'Andro-miRs': let-7c, miR-31, miR-124, miR-185, miR-205 and miR-488 downregulate AR expression (Massillo et al. 2017). Notably, the top four downregulated miRNAs in PCa tissues are miR-187, miR-205, miR-222 and miR-31 (Fuse et al. 2012). Additional tumor suppressor miRNAs in PCa and their targets include miR-331-3p that downregulates ERBB2 and AR and is associated with castration-resistant PCa (reviewed in Kanwal et al. 2017). miRNAs associated with metastasis include downregulation of miR-1, miR-15, miR-16, miR-23a, miR-29b, miR-126, miR-130, miR-132, miR-141, miR-195, miR-200b, miR-200c, miR-203, miR-205, miR-218, miR-375, miR-377, miR-466, miR-573, miR-675, and miR-802 and upregulation of miR-21, miR-22, miR-25, miR-93, miR-106b, miR-154-3p, miR-379, miR-543 and miR-590-3p (reviewed in Massillo et al. 2017). miRNAs upregulated or downregulated in serum, plasma and urine with potential prognostic value in separating men with potentially lethal PCa vs indolent disease were recently reviewed (Massillo et al. 2017).

\section{Dysregulation of miRNAs in EC}

EC is the most frequently diagnosed gynecological cancer (Siegel et al. 2017). Among the miRNAs differentially expressed in EC vs normal endometrial tissue are the increased expression of miR-10b, miR-21, miR-31, miR-182, miR-183, miR-205, miR-222, miR-223, miR-410, miR-429, miR-449a, miR-994, and miR-1228; and downregulation of let-7, miR-34b-5p, miR-34c-3p, miR-34c-5p, miR-99b, miR-101, miR-130a, miR-143, miR-145, miR-184, miR-193b, miR-204, miR-340, miR-372, miR-429, miR-449a, miR-490 and miR-495 (reviewed in Srivastava et al. 2017). In serum samples from women with EC, increased levels of miR-186, miR-222 and miR-223 were identified compared with controls (Montagnana etal. 2017). Targets of upregulated miRs in EC include the tumor suppressor PTEN that is downregulated by overexpressed miR-21, miR-130a, miR-205, miR-222 and miR-429 (Srivastava et al. 2017). Although much studied, there are currently no miRNA signatures in use for early detection and screening of gynecological cancers (Srivastava et al. 2017).

\section{miRNAs in thyroid cancer}

The identity and targets of miRNAs dysregulated in PTC and follicular thyroid carcinoma (FTC) have been recently 
reviewed (Pallante et al. 2013, Saiselet et al. 2016, Yoo et al. 2016, Celano et al. 2017, Lima et al. 2017, Pishkari et al. 2018). miRNAs upregulated in PTC include miR-21, miR-31, miR-99-3p, miR-128a, miR-128b, miR-139, miR-141, miR-146a, miR-146b-3p, miR-146b-5p, miR-155, miR-181a, miR-181b, miR-187, miR-191, miR-200a, miR-200b, miR-200c, miR-220, miR-221, miR-222, miR-222-5p, miR-224, miR-375, miR-551b (Pallante et al. 2013). Downregulated miRNAs in PTC include: let-7f, miR-1, miR-26a-1, miR-30, miR-30c, miR-138, miR-199, miR-219, miR-292, miR-300 and miR-345 (Pallante et al. 2013). With RNA-seq, thearm of eachmiRNAandisomiRNAs can be detected. Thus, RNA-seq has higher resolution and detected increased miR-21-3p, miR-21-5p, miR-31-3p, miR-31-5p, miR-34a-5p, miR-146-3p, miR-146-5p, miR-182-5p, miR-183-5p, miR-221-3p, miR-221-5p, miR-222-3p and miR-551b-3p in PTC (Saiselet et al. 2016). RNA-seq identified miRNAs upregulated in FTC include miR-96-5p, miR-182-5p, miR-221-3p, miR-183-5p and miR-222-3p, whereas miR-31-5p, miR-199a-5p and miR-199b-5p showed consistent downregulation in three independent studies (reviewed in Saiselet et al. 2016).

\section{miRNAs in mitochondria}

Mitochondrial function is critical for metabolic homeostasis. NGS has identified several miRNAs imported into mitochondria including miR-34, miR-181c-5p and miR-146a-5p (Kim et al. 2017b). The identity and roles of miRNAs in mitochondrial biology were recently reviewed (Vendramin et al. 2017). The term 'mitomiRs' refers to miRNAs functioning in mitochondria, whether nuclearor mtDNA-encoded (Duarte et al. 2015). mitomiRs are $17-25 \mathrm{nt}$ vs the canonical $22 \mathrm{nt}$ for most miRNAs. The exact function and identity of mitomiRs remains unknown and caution is advised since cytoplasmic contamination of mitochondrial extracts is problematic (Vendramin et al. 2017). Many ncRNAs appear to be involved in rapid cell stress responses and may be involved in anterograde and retrograde signaling between the nucleus and mitochondria to regulate energy homeostasis and apoptosis. For example, miRNAs appear to provide anterograde regulation of mitochondrial function, apoptosis and cancer cell metabolism (Duarte et al. 2015, Cha et al. 2017). However, although mitochondrial dysfunction is a hallmark of cancer, the role of ncRNAs in the mitochondrial unfolded protein response (UPRmt) in cancer (reviewed in Kenny \& Germain 2017) remains to be examined.

\section{miRNAs in circulation}

Screening of free and exosomal-associated miRNAs by high-throughput sequencing platforms has identified changes in breast, ovarian and prostate cancers (Smith et al. 2017) and in thyroid cancer (Saiselet et al. 2016). The release of exosomes containing miRNAs (as well as other ncRNAs, protein and lipids) and endocytic uptake of the exosomes in recipient cells results in altered regulation of gene translation and has implicated miRNAs as hormones (reviewed in Bayraktar et al. 2017). In addition, circulating miRNAs can be transported between cells by microvesicles, apoptotic bodies, lipoproteins (HDL) and ribonucleoproteins, e.g., nucleophosmin 1 and AGO2. Exosomes derived from patients with CRPCa have increased expression of miR-1290 and miR-375 and correlate with decreased overall survival (reviewed in Kanwal et al. 2017). CAFs stimulate cancer progression by secreting chemokines, cytokines and growth factors that create the extracellular matrix (ECM) and CAFs secrete EVs containing a different spectrum of miRNAs compared to normal fibroblasts (Bayraktar et al. 2017). Among the miRNAs secreted by CAFs that regulate cancer cells are miR-21, miR-143 and miR-378 in BCa (Donnarumma et al. 2017); miR-210, miR-409-3p/5p (Yang et al. 2017a) and miR-409 (Josson et al. 2014) in PCa cells; and miR-21 in ovarian cancer (Au Yeung et al. 2016). Tumor-associated macrophages (TAMs) are also donors of miRNAs in cancer (reviewed in Bayraktar et al. 2017). Increased TAMs is associated with poor survival in advanced thyroid cancer (Ryder et al. 2008).

The mandate from NIH in the Precision Medicine Initiate is to have data-driven care for patients. A current goal of clinical trials is to determine if miRNA signatures obtained in fine needle aspiration biopsies and blood (serum or plasma) or urine will provide early diagnosis and track with therapeutic responses in cancer patients. However, the miRNA expression profile identified in blood samples depends on the processing of the sample, the miRNA extraction method, contamination, including by lysis of blood cells, and which normalizers are used (Saiselet et al. 2016). In addition to the ongoing efforts to standardize exosome and miRNA purification from biological fluids, factors that impact variability in miRNAs detected in circulation include diet, physical activity and circadian rhythms (reviewed in Smith et al. 2017). Most of the clinical trials involving mRNAs are observational, i.e., examining circulating in PCa, ovarian and breast cancers to monitor therapeutic responses to chemotherapy or other treatment strategies (reviewed in Smith et al. 2017). 


\section{miRNA therapeutics}

Despite the large body of literature supporting miRNAs as biomarkers for diagnosis, prognosis and follow-up in patients with malignancies, the application of miRNA therapeutics into the clinical practice has a number of technical obstacles to overcome include clearance and optimization of bioavailability (reviewed in Chen et al. 2015). Nanoformulations of miRNAs, miRNA mimics, miRNA sponges, anti-miR oligonucleotides (AMOs) and small-molecule inhibitors are being tested in animal models. miRNA mimics to replace the expression of downregulated miRNAs by synthetic oligonucleotides that are combined with hydrogels, liposomes, minicells, nanoparticles, synthetic polymers or viral carriers for better delivery are under investigation (Drusco \& Croce 2017). Recently, a folate-miR-34a-5p conjugate was shown to be taken by MDA-MB-231 cells, which have high folate receptor levels and to inhibit MDA-MB-231 xenograft tumor growth in mice (Orellana et al. 2017). 'AntagomiRs' serve to inhibit oncomiR function, e.g., a miR-10b antagomiR to mice did not inhibit primary mammary tumor growth, but inhibited lung metastasis (Ma et al. 2010) and intraperitoneal injection of a miR-92a-LNA inhibitor inhibited human EC cell xenograft growth in mice with no evidence of overt toxicity or metastatic spread (Torres et al. 2016). However, many challenges remain for therapeutics with or against miRNAs, notably the contradictory nature of miRNAs.

\section{Conclusions}

lncRNAs and miRNAs dysregulated in endocrine cancers, and they serve as biomarkers and potential therapeutic targets and agents in various cancers and other diseases, e.g., cardiovascular disease and type II diabetes. These and other ncRNAs are interconnected and have complex molecular roles in regulating protein-coding and noncoding nuclear gene transcription: RNA stability, epigenetic processes, chromatin accessibility, translation, gene expression in mitochondria, anterograde and retrograde signaling and intracellular and intercellular signaling. The study of lncRNAs is less mature than that of miRNAs. For example, new lncRNAs continue to be discovered, relatively few studies on any specific IncRNA have been published, and each lncRNA may have multiple isoforms that can be post-transcriptionally modified, adding complexity to evaluating their cellular and physiologic function. IncRNA structures are functionally important, but only a few IncRNAs' structures are known. Identification of cell-specific lncRNA-interacting proteins and other RNAs and their subcellular distribution is needed. Both miRNAs and IncRNAs are being actively evaluated as tumor biopsy, plasma, serum, blood and urine biomarkers in the diagnosis and management of endocrine-related cancers as well as therapeutic targets. In addition, lncRNAs and miRNAs may serve as therapeutic agents. Many challenges remain in elucidating the biogenesis and function of ncRNAs in endocrine-related cancers. Our understanding of the functional roles of miRNAs and IncRNAs and their molecular targets is expanding rapidly. However, individual miRNAs and lncRNAs, and their combinations, may have different sets of targets and activities depending on the cell type, microenvironment, microbiome and hormonal milieu; thus, further investigation is required to fully elucidate miRNA and lncRNA function in endocrine-related cancers.

\section{Supplementary data}

This is linked to the online version of the paper at https://doi.org/10.1530/ ERC-17-0548.

Declaration of interest

The author declares that there is no conflict of interest that could be perceived as prejudicing the impartiality of this review.

\section{Funding}

This work did not receive any specific grant from any funding agency in the public, commercial or not-for-profit sector.

\section{References}

Aiello A, Bacci L, Re A, Ripoli C, Pierconti F, Pinto F, Masetti R, Grassi C, Gaetano C, Bassi PF, et al. 2016 MALAT1 and HOTAIR long noncoding RNAs play opposite role in estrogen-mediated transcriptional regulation in prostate cancer cells. Science Reports 6 38414. (https:// doi.org/10.1038/srep38414)

Alahari SV, Eastlack SC \& Alahari SK 2016 Role of long noncoding RNAs in neoplasia: special emphasis on prostate cancer. International Review of Cell and Molecular Biology 324 229-254. (https://doi.org/10.1016/ bs.ircmb.2016.01.004)

Andersson R, Gebhard C, Miguel-Escalada I, Hoof I, Bornholdt J, Boyd M, Chen Y, Zhao X, Schmidl C, Suzuki T, et al. 2014 An atlas of active enhancers across human cell types and tissues. Nature $\mathbf{5 0 7}$ 455-461. (https://doi.org/10.1038/nature12787)

Andersson S, Sundberg M, Pristovsek N, Ibrahim A, Jonsson P, Katona B, Clausson C-M, Zieba A, Ramström M, Söderberg O, et al. 2017 Insufficient antibody validation challenges oestrogen receptor beta research. Nature Communications 8 15840. (https://doi.org/10.1038/ ncomms15840)

Arun G, Diermeier S, Akerman M, Chang KC, Wilkinson JE, Hearn S, Kim Y, MacLeod AR, Krainer AR, Norton L, et al. 2016 Differentiation of mammary tumors and reduction in metastasis upon Malat1
(C) 2018 Society for Endocrinology Published by Bioscientifica Ltd. Printed in Great Britain 
IncRNA loss. Genes and Development 30 34-51. (https://doi. org/10.1101/gad.270959.115)

$\mathrm{Au}$ Yeung CL, Co N-N, Tsuruga T, Yeung T-L, Kwan S-Y, Leung CS, Li Y, Lu ES, Kwan K, Wong K-K, et al. 2016 Exosomal transfer of stromaderived miR21 confers paclitaxel resistance in ovarian cancer cells through targeting APAF1. Nature Communications 7 11150. (https:// doi.org/10.1038/ncomms11150)

Barrett SP \& Salzman J 2016 Circular RNAs: analysis, expression and potential functions. Development 143 1838. (https://doi.org/10.1242/ dev.128074)

Barsotti AM \& Prives C 2010 Noncoding RNAs: the missing 'Linc' in p53-mediated repression. Cell 142 358-360. (https://doi. org/10.1016/j.cell.2010.07.029)

Bayraktar R, Van Roosbroeck K \& Calin GA 2017 Cell-to-cell communication: microRNAs as hormones. Molecular Oncology 11 1673-1686. (https://doi.org/10.1002/1878-0261.12144)

Bhan A, Hussain I, Ansari KI, Kasiri S, Bashyal A \& Mandal SS 2013 Antisense transcript long noncoding RNA (lncRNA) HOTAIR is transcriptionally induced by estradiol. Journal of Molecular Biology 425 3707-3722. (https://doi.org/10.1016/j.jmb.2013.01.022)

Bhan A, Deb P, Shihabeddin N, Ansari KI, Brotto M \& Mandal SS 2017 Histone methylase MLL1 coordinates with HIF and regulate lncRNA HOTAIR expression under hypoxia. Gene 629 16-28. (https://doi. org/10.1016/j.gene.2017.07.069)

Brown JA, Bulkley D, Wang J, Valenstein ML, Yario TA, Steitz TA \& Steitz JA 2014 Structural insights into the stabilization of MALAT1 noncoding RNA by a bipartite triple helix. Nature Structural and Molecular Biology 21 633. (https://doi.org/10.1038/nsmb.2844)

Burger K, Schlackow M, Potts M, Hester S, Mohammed S \& Gullerova M 2017 Nuclear phosphorylated Dicer processes double-stranded RNA in response to DNA damage. Journal of Cell Biology 2162373. (https://doi.org/10.1083/jcb.201612131)

Burzio VA, Villota C, Villegas J, Landerer E, Boccardo E, Villa LL, Martínez R, Lopez C, Gaete F, Toro V, et al. 2009 Expression of a family of noncoding mitochondrial RNAs distinguishes normal from cancer cells. PNAS 106 9430-9434. (https://doi.org/10.1073/ pnas.0903086106)

Cai X, Hagedorn CH \& Cullen BR 2004 Human microRNAs are processed from capped, polyadenylated transcripts that can also function as mRNAs. RNA 10 1957-1966. (https://doi.org/10.1261/ rna.7135204)

Cava C, Bertoli G, Ripamonti M, Mauri G, Zoppis I, Della Rosa PA, Gilardi MC \& Castiglioni I 2014 Integration of mRNA expression profile, copy number alterations, and microRNA expression levels in breast cancer to improve grade definition. PLOS ONE 9 e97681. (https://doi.org/10.1371/journal.pone.0097681)

Celano M, Rosignolo F, Maggisano V, Pecce V, Iannone M, Russo D \& Bulotta S 2017 MicroRNAs as biomarkers in thyroid carcinoma. International Journal of Genomics 2017 6496570. (https://doi. org $/ 10.1155 / 2017 / 6496570)$

Cerase A, Pintacuda G, Tattermusch A \& Avner P 2015 Xist localization and function: new insights from multiple levels. Genome Biology 16 166. (https://doi.org/10.1186/s13059-015-0733-y)

Cha YJ, Lee JH, Han HH, Kim BG, Kang S, Choi YD \& Cho NH 2016 MicroRNA alteration and putative target genes in high-grade prostatic intraepithelial neoplasia and prostate cancer: STAT3 and ZEB1 are upregulated during prostate carcinogenesis. Prostate $\mathbf{7 6}$ 937-947. (https://doi.org/10.1002/pros.23183)

Cha Y, Han M-J, Cha H-J, Zoldan J, Burkart A, Jung JH, Jang Y, Kim C-H, Jeong H-C, Kim B-G, et al. 2017 Metabolic control of primed human pluripotent stem cell fate and function by the miR-200c-SIRT2 axis. Nature Cell Biology 19 445. (https://doi.org/10.1038/ncb3517)

Chakravarty D, Sboner A, Nair SS, Giannopoulou E, Li R, Hennig S, Mosquera JM, Pauwels J, Park K, Kossai M, et al. 2014 The oestrogen receptor alpha-regulated lncRNA NEAT1 is a critical modulator of prostate cancer. Nature Communications 5 5383. (https://doi. org/10.1038/ncomms6383)

Chaligne R, Popova T, Mendoza-Parra MA, Saleem MA, Gentien D, Ban K, Piolot T, Leroy O, Mariani O, Gronemeyer H, et al. 2015 The inactive $\mathrm{X}$ chromosome is epigenetically unstable and transcriptionally labile in breast cancer. Genome Research 25 488-503. (https://doi.org/10.1101/gr.185926.114)

Chen Y, Gao D-Y \& Huang L 2015 In vivo delivery of miRNAs for cancer therapy: challenges and strategies. Advanced Drug Delivery Reviews $\mathbf{8 1}$ 128-141. (https://doi.org/10.1016/j.addr.2014.05.009)

Chen ZJ, Zhang Z, Xie BB \& Zhang HY 2016 Clinical significance of up-regulated IncRNA NEAT1 in prognosis of ovarian cancer. European Review for Medical and Pharmacological Sciences 20 3373-3377.

Chen YG, Satpathy AT \& Chang HY 2017 Gene regulation in the immune system by long noncoding RNAs. Nature Immunology 18 962-972. (https://doi.org/10.1038/ni.3771)

Chillón I \& Pyle AM 2016 Inverted repeat Alu elements in the human lincRNA-p21 adopt a conserved secondary structure that regulates RNA function. Nucleic Acids Research 44 9462-9471.

Chiyomaru T, Yamamura S, Fukuhara S, Yoshino H, Kinoshita T, Majid S, Saini S, Chang I, Tanaka Y, Enokida H, et al. 2013 Genistein inhibits prostate cancer cell growth by targeting miR-34a and oncogenic HOTAIR. PLOS ONE 8 e70372. (https://doi.org/10.1371/journal. pone.0070372)

Chiyomaru T, Fukuhara S, Saini S, Majid S, Deng G, Shahryari V, Chang I, Tanaka Y, Enokida H, Nakagawa M, et al. 2014 Long noncoding RNA HOTAIR is targeted and regulated by miR-141 in human cancer cells. Journal of Biological Chemistry 289 12550-12565. (https://doi.org/10.1074/jbc.M113.488593)

Chou SD, Murshid A, Eguchi T, Gong J \& Calderwood SK 2015 HSF1 regulation of [beta]-catenin in mammary cancer cells through control of HuR/elavL1 expression. Oncogene 34 2178-2188. (https:// doi.org/10.1038/onc.2014.177)

Chun-Jiao S, Huan C, Li-Zhong C, Guo-Mei R, Jian-Jun G \& Qian-Nan D 2017 The potential of microRNAs as human prostate cancer biomarkers: a meta-analysis of related studies. Journal of Cellular Biochemistry 119 2763-2786. (https://doi.org/10.1002/jcb.26445)

Cinghu S, Yang P, Kosak JP, Conway AE, Kumar D, Oldfield AJ, Adelman K \& Jothi R 2017 Intragenic enhancers attenuate host gene expression. Molecular Cell 68 104.e106-117.e106. (https://doi. org/10.1016/j.molcel.2017.09.010)

Clarke R, Tyson JJ \& Dixon JM 2015 Endocrine resistance in breast cancer - an overview and update. Molecular and Cellular Endocrinology 418 220-234. (https://doi.org/10.1016/j.mce.2015.09.035)

Colley SM, Wintle L, Searles R, Russell V, Firman RC, Smith S, DeBoer K, Merriner DJ, Genevieve B, Bentel JM, et al. 2013 Loss of the nuclear receptor corepressor SLIRP compromises male fertility. PLOS ONE $\mathbf{8}$ e70700. (https://doi.org/10.1371/journal.pone.0070700)

Creamer KM \& Lawrence JB 2017 XIST RNA: a window into the broader role of RNA in nuclear chromosome architecture. Philosophical Transactions of the Royal Society of London, Series B: Biological Sciences 372 20160360. (https://doi.org/10.1098/rstb.2016.0360)

da Rocha ST \& Heard E 2017 Novel players in X inactivation: insights into Xist-mediated gene silencing and chromosome conformation. Nature Structural and Molecular Biology 24 197-204. (https://doi. org/10.1038/nsmb.3370)

Darnell RB 2010 HITS-CLIP: panoramic views of protein-RNA regulation in living cells. Wiley Interdisciplinary Reviews: RNA 1 266-286. (https://doi.org/10.1002/wrna.31)

Daugaard I \& Hansen TB 2017 Biogenesis and function of ago-associated RNAs. Trends in Genetics 33 208-219. (https://doi.org/10.1016/j. tig.2017.01.003)

de Kock L, Sabbaghian N, Soglio DB, Guillerman RP, Park BK, Chami R, Deal CL, Priest JR \& Foulkes WD 2014 Exploring the association between DICER1 mutations and differentiated thyroid carcinoma. (c) 2018 Society for Endocrinology Published by Bioscientifica Ltd. Printed in Great Britain 
Journal of Clinical Endocrinology and Metabolism 99 E1072-E1077. (https://doi.org/10.1210/jc.2013-4206)

De Paepe B, Lefever S \& Mestdagh P 2017 How long noncoding RNAs enforce their will on mitochondrial activity: regulation of mitochondrial respiration, reactive oxygen species production, apoptosis, and metabolic reprogramming in cancer. Current Genetics 64 163-172. (https://doi.org/10.1007/s00294-017-0744-1)

Delas MJ \& Hannon GJ 2017 lncRNAs in development and disease: from functions to mechanisms. Open Biology 7 170121. (https://doi. org/10.1098/rsob.170121)

Dimitrova N, Zamudio Jesse R, Jong Robyn M, Soukup D, Resnick R, Sarma K, Ward Amanda J, Raj A, Lee Jeannie T, Sharp Phillip A, et al. 2014 LincRNA-p21 activates p21 In cis to promote polycomb target gene expression and to enforce the G1/S checkpoint. Molecular Cell 54 777-790. (https://doi.org/10.1016/j.molcel.2014.04.025)

Ding W, Ren J, Ren H \& Wang D 2017 Long noncoding RNA HOTAIR modulates MiR-206-mediated Bcl-w signaling to facilitate cell proliferation in breast cancer. Scientific Reports 7 17261. (https://doi. org/10.1038/s41598-017-17492-x)

Djebali S, Davis CA, Merkel A, Dobin A, Lassmann T, Mortazavi A, Tanzer A, Lagarde J, Lin W, Schlesinger F, et al. 2012 Landscape of transcription in human cells. Nature 489 101-108. (https://doi. org/10.1038/nature11233)

Dong Y, Yoshitomi T, Hu JF \& Cui J 2017 Long noncoding RNAs coordinate functions between mitochondria and the nucleus. Epigenetics and Chromatin 10 41. (https://doi.org/10.1186/s13072017-0149-x)

Donnarumma E, Fiore D, Nappa M, Roscigno G, Adamo A, Iaboni M, Russo V, Affinito A, Puoti I, Quintavalle C, et al. 2017 Cancerassociated fibroblasts release exosomal microRNAs that dictate an aggressive phenotype in breast cancer. Oncotarget 8 19592-19608. (https://doi.org/10.18632/oncotarget.14752)

Drusco A \& Croce CM 2017 Chapter one - microRNAs and cancer: a long story for short RNAs. In Advances in Cancer Research, pp 1-24. Eds CM Croce \& PB Fisher. Cambridge, MA, USA: Academic Press.

Duarte FV, Palmeira CM \& Rolo AP 2015 The emerging role of mitomiRs in the pathophysiology of human disease. Advances in Experimental Medicine and Biology 888 123-154. (https://doi.org/10.1007/978-3319-22671-2 8)

Dykes IM \& Emanueli C 2017 Transcriptional and post-transcriptional gene regulation by long non-coding RNA. Genomics, Proteomics and Bioinformatics 15 177-186. (https://doi.org/10.1016/j.gpb.2016.12.005)

Egeland NG, Lunde S, Jonsdottir K, Lende TH, Cronin-Fenton D, Gilje B, Janssen EA \& Soiland H 2015 The role of microRNAs as predictors of response to tamoxifen treatment in breast cancer patients. International Journal of Molecular Sciences 16 24243-24275. (https:// doi.org/10.3390/ijms161024243)

Ellis MJ, Ding L, Shen D, Luo J, Suman VJ, Wallis JW, Van Tine BA, Hoog J, Goiffon RJ, Goldstein TC, et al. 2012 Whole-genome analysis informs breast cancer response to aromatase inhibition. Nature 486 353-360. (https://doi.org/10.1038/nature11143)

ENCODE Project Consortium 2012 An integrated encyclopedia of DNA elements in the human genome. Nature 489 57-74. (https://doi. org/10.1038/nature11247)

Farazi TA, Ten Hoeve JJ, Brown M, Mihailovic A, Horlings HM, van de Vijver MJ, Tuschl T \& Wessels LF 2014 Identification of distinct miRNA target regulation between breast cancer molecular subtypes using AGO2-PAR-CLIP and patient datasets. Genome Biology 15 R9. (https://doi.org/10.1186/gb-2014-15-1-r9)

Fernandez N, Cordiner RA, Young RS, Hug N, Macias S \& Cáceres JF 2017 Genetic variation and RNA structure regulate microRNA biogenesis. Nature Communications 8 15114. (https://doi.org/10.1038/ ncomms15114)

Friedman RC, Farh KK, Burge CB \& Bartel DP 2009 Most mammalian mRNAs are conserved targets of microRNAs. Genome Research 19 92-105. (https://doi.org/10.1101/gr.082701.108)
Fritah S, Niclou SP \& Azuaje F 2014 Databases for lncRNAs: a comparative evaluation of emerging tools. RNA 20 1655-1665. (https://doi.org/10.1261/rna.044040.113)

Fuse M, Kojima S, Enokida H, Chiyomaru T, Yoshino H, Nohata N, Kinoshita T, Sakamoto S, Naya Y, Nakagawa M, et al. 2012 Tumor suppressive microRNAs (miR-222 and miR-31) regulate molecular pathways based on microRNA expression signature in prostate cancer. Journal of Human Genetics 57 691. (https://doi.org/10.1038/ jhg.2012.95)

Gainetdinov I, Skvortsova Y, Kondratieva S, Funikov S \& Azhikina T 2017 Two modes of targeting transposable elements by piRNA pathway in human testis. RNA 23 1614-1625. (https://doi. org/10.1261/rna.060939.117)

Gao S, Tian X, Chang H, Sun Y, Wu Z, Cheng Z, Dong P, Zhao Q, Ruan J $\&$ Bu W 2017 Two novel lncRNAs discovered in human mitochondrial DNA using PacBio full-length transcriptome data. Mitochondrion 38 41-47. (https://doi.org/10.1016/j.mito.2017.08.002)

Guo C, Song WQ, Sun P, Jin L \& Dai HY 2015 LncRNA-GAS5 induces PTEN expression through inhibiting miR-103 in endometrial cancer cells. Journal of Biomedical Science 22 100. (https://doi.org/10.1186/ s12929-015-0213-4)

Guo H, Ahmed M, Zhang F, Yao CQ, Li S, Liang Y, Hua J, Soares F, Sun Y, Langstein J, et al. 2016 a Modulation of long noncoding RNAs by risk SNPs underlying genetic predispositions to prostate cancer. Nature Genetics 48 1142. (https://doi.org/10.1038/ng.3637)

Guo Q, Qian Z, Yan D, Li L \& Huang L $2016 b$ LncRNA-MEG3 inhibits cell proliferation of endometrial carcinoma by repressing Notch signaling. Biomedicine and Pharmacotherapy 82 589-594. (https://doi. org/10.1016/j.biopha.2016.02.049)

Guo L-J, Zhang S, Gao B, Jiang Y, Zhang X-H, Tian W-G, Hao S, Zhao J-J, Zhang G, Hu C-Y, et al. 2017 Low expression of long non-coding RNA GAS5 is associated with poor prognosis of patients with thyroid cancer. Experimental and Molecular Pathology 102 500-504. (https:// doi.org/10.1016/j.yexmp.2017.05.008)

Ha M \& Kim VN 2014 Regulation of microRNA biogenesis. Nature Reviews Molecular Cell Biology 15 509-524. (https://doi.org/10.1038/ nrm3838)

Hajjari M \& Salavaty A 2015 HOTAIR: an oncogenic long non-coding RNA in different cancers. Cancer Biology \& Medicine 12 1-9. (https:// doi.org/10.7497/j.issn.2095-3941.2015.0006)

Hansji H, Leung EY, Baguley BC, Finlay GJ, Cameron-Smith D, Figueiredo VC \& Askarian-Amiri ME 2016 ZFAS1: a long noncoding RNA associated with ribosomes in breast cancer cells. Biology Direct 11 62. (https://doi.org/10.1186/s13062-016-0165-y)

Hata A \& Kashima R 2016 Dysregulation of microRNA biogenesis machinery in cancer. Critical Reviews in Biochemistry and Molecular Biology 51 121-134. (https://doi.org/10.3109/10409238.2015.1117054)

Hatchell EC, Colley SM, Beveridge DJ, Epis MR, Stuart LM, Giles KM, Redfern AD, Miles LEC, Barker A, MacDonald LM, et al. 2006 SLIRP, a small SRA binding protein, is a nuclear receptor corepressor. Molecular Cell 22 657-668. (https://doi.org/10.1016/j. molcel.2006.05.024)

Heilmann K, Toth R, Bossmann C, Klimo K, Plass C \& Gerhauser C 2017 Genome-wide screen for differentially methylated long noncoding RNAs identifies Esrp2 and lncRNA Esrp2-as regulated by enhancer DNA methylation with prognostic relevance for human breast cancer. Oncogene 36 6446. (https://doi.org/10.1038/onc.2017.246)

Hilz S, Modzelewski AJ, Cohen PE \& Grimson A 2016 The roles of microRNAs and siRNAs in mammalian spermatogenesis. Development 143 3061. (https://doi.org/10.1242/dev.136721)

Hock J \& Meister G 2008 The Argonaute protein family. Genome Biology 9 210. (https://doi.org/10.1186/gb-2008-9-2-210)

Hon C-C, Ramilowski JA, Harshbarger J, Bertin N, Rackham OJL, Gough J, Denisenko E, Schmeier S, Poulsen TM, Severin J, et al. 2017 An atlas of human long non-coding RNAs with accurate $5^{\prime}$ ends. Nature 543 199-204. (https://doi.org/10.1038/nature21374)
(2) 2018 Society for Endocrinology Published by Bioscientifica Ltd. Printed in Great Britain 
Hong E, Best A, Gautrey H, Chin J, Razdan A, Curk T, Elliott DJ \& Tyson-Capper AJ 2015 Unravelling the RNA-binding properties of SAFB proteins in breast cancer cells. BioMed Research International 2015 395816. (https://doi.org/10.1155/2015/395816)

Hosseini ES, Meryet-Figuiere M, Sabzalipoor H, Kashani HH, Nikzad H \& Asemi Z 2017 Dysregulated expression of long noncoding RNAs in gynecologic cancers. Molecular Cancer 16 107. (https://doi. org/10.1186/s12943-017-0671-2)

Hu W, Alvarez-Dominguez JR \& Lodish HF 2012 Regulation of mammalian cell differentiation by long non-coding RNAs. EMBO Reports 13 971-983. (https://doi.org/10.1038/embor.2012.145)

Huang J-K, Ma L, Song W-H, Lu B-Y, Huang Y-B, Dong H-M, Ma X-K, Zhu Z-Z \& Zhou R 2016a MALAT1 promotes the proliferation and invasion of thyroid cancer cells via regulating the expression of IQGAP1. Biomedicine and Pharmacotherapy 83 1-7. (https://doi. org/10.1016/j.biopha.2016.05.039)

Huang YS, Chang CC, Lee SS, Jou YS \& Shih HM 2016b Xist reduction in breast cancer upregulates AKT phosphorylation via HDAC3mediated repression of PHLPP1 expression. Oncotarget 7 43256-43266. (https://doi.org/10.18632/oncotarget.9673)

Huarte M 2015 The emerging role of lncRNAs in cancer. Nature Medicine 21 1253-1261. (https://doi.org/10.1038/nm.3981)

Iorio MV, Ferracin M, Liu CG, Veronese A, Spizzo R \& Sabbioni S 2005 MicroRNA gene expression deregulation in human breast cancer. Cancer Research 65 7065-7070. (https://doi.org/10.1158/0008-5472. CAN-05-1783)

Jarroux J, Morillon A \& Pinskaya M 2017 History, discovery, and classification of lncRNAs. Advances in Experimental Medicine and Biology 1008 1-46. (https://doi.org/10.1007/978-981-10-5203-3_1)

Jeselsohn R, Cornwell M, Pun M, Buchwalter G, Nguyen M, Bango C, Huang Y, Kuang Y, Paweletz C, Fu X, et al. 2017 Embryonic transcription factor SOX9 drives breast cancer endocrine resistance. PNAS 114 E4482-E4491. (https://doi.org/10.1073/pnas.1620993114)

Josson S, Gururajan M, Sung SY, Hu P, Shao C, Zhau HE, Liu C, Lichterman J, Duan P, Li Q, et al. 2014 Stromal fibroblast-derived miR-409 promotes epithelial-to-mesenchymal transition and prostate tumorigenesis. Oncogene 34 2690. (https://doi.org/10.1038/ onc.2014.212)

Kanwal R, Plaga AR, Liu X, Shukla GC \& Gupta S 2017 MicroRNAs in prostate cancer: functional role as biomarkers. Cancer Letters $\mathbf{4 0 7}$ 9-20. (https://doi.org/10.1016/j.canlet.2017.08.011)

Kawaji H, Kasukawa T, Forrest A, Carninci P \& Hayashizaki Y 2017 The FANTOM5 collection, a data series underpinning mammalian transcriptome atlases in diverse cell types. Scientific Data 4170113. (https://doi.org/10.1038/sdata.2017.113)

Kawashima H, Takano H, Sugita S, Takahara Y, Sugimura K \& Nakatani T 2003 A novel steroid receptor co-activator protein (SRAP) as an alternative form of steroid receptor RNA-activator gene: expression in prostate cancer cells and enhancement of androgen receptor activity. Biochemical Journal 369 163. (https://doi.org/10.1042/ bj20020743)

Kenny TC \& Germain D 2017 mtDNA, metastasis, and the mitochondrial unfolded protein response (UPRmt). Frontiers in Cell and Developmental Biology 5 37. (https://doi.org/10.3389/ fcell.2017.00037)

Khan NE, Bauer AJ, Schultz KAP, Doros L, Decastro RM, Ling A, Lodish MB, Harney LA, Kase RG, Carr AG, et al. 2017 Quantification of thyroid cancer and multinodular goiter risk in the DICER1 syndrome: a family-based cohort study. Journal of Clinical Endocrinology and Metabolism 102 1614-1622. (https://doi. org/10.1210/jc.2016-2954)

Kim T-K, Hemberg M \& Gray JM 2015 Enhancer RNAs: a class of long noncoding RNAs synthesized at enhancers. Cold Spring Harbor Perspectives in Biology 7 a018622. (https://doi.org/10.1101/ cshperspect.a018622)
Kim KM, Abdelmohsen K, Mustapic M, Kapogiannis D \& Gorospe M $2017 a$ RNA in extracellular vesicles. Wiley Interdisciplinary Reviews: RNA 8 e1413. (https://doi.org/10.1002/wrna.1413)

Kim KM, Noh JH, Abdelmohsen K \& Gorospe M 2017b Mitochondrial noncoding RNA transport. BMB Reports 50 164-174. (https://doi. org/10.5483/BMBRep.2017.50.4.013)

Kino T, Hurt DE, Ichijo T, Nader N \& Chrousos GP 2010 Noncoding RNA Gas5 is a growth arrest- and starvation-associated repressor of the glucocorticoid receptor. Science Signaling 3 ra8. (https://doi. org/10.1126/scisignal.2000568)

Klinge CM 2015 miRNAs regulated by estrogens, tamoxifen, and endocrine disruptors and their downstream gene targets. Molecular and Cellular Endocrinology 418 273-297. (https://doi.org/10.1016/j. mce.2015.01.035)

Kojima S, Goto Y \& Naya Y 2017 The roles of microRNAs in the progression of castration-resistant prostate cancer. Journal of Human Genetics 62 25-31. (https://doi.org/10.1038/jhg.2016.69)

Kotan LD, Cooper C, Darcan S, Carr IM, Ozen S, Yan Y, Hamedani MK, Gurbuz F, Mengen E, Turan I, et al. 2016 Idiopathic hypogonadotropic hypogonadism caused by inactivating mutations in SRA1. Journal of Clinical Research in Pediatric Endocrinology 8 125-134. (https://doi.org/10.4274/jcrpe.3248)

Kouros-Mehr H, Slorach EM, Sternlicht MD \& Werb Z 2006 GATA-3 maintains the differentiation of the luminal cell fate in the mammary gland. Cell 127 1041-1055. (https://doi.org/10.1016/j. cell.2006.09.048)

Kozomara A \& Griffiths-Jones S 2014 miRBase: annotating high confidence microRNAs using deep sequencing data. Nucleic Acids Res 42 D68-D73. (https://doi.org/10.1093/nar/gkt1181)

Kumarswamy R, Bauters C, Volkmann I, Maury F, Fetisch J, Holzmann A, Lemesle G, de Groote P, Pinet F \& Thum T 2014 Circulating long noncoding RNA, LIPCAR, predicts survival in patients with heart failure. Circulation Research 114 1569-1575. (https://doi.org/10.1161/CIRCRESAHA.114.303915)

Kurzynska-Kokorniak A, Koralewska N, Pokornowska M, Urbanowicz A, Tworak A, Mickiewicz A \& Figlerowicz M 2015 The many faces of Dicer: the complexity of the mechanisms regulating Dicer gene expression and enzyme activities. Nucleic Acids Research $\mathbf{4 3}$ 4365-4380. (https://doi.org/10.1093/nar/gkv328)

Lam MTY, Li W, Rosenfeld MG \& Glass CK 2014 Enhancer RNAs and regulated transcriptional programs. Trends in Biochemical Sciences 39 170-182. (https://doi.org/10.1016/j.tibs.2014.02.007)

Lan X, Zhang H, Wang Z, Dong W, Sun W, Shao L, Zhang T \& Zhang D 2015 Genome-wide analysis of long noncoding RNA expression profile in papillary thyroid carcinoma. Gene 569 109-117. (https:// doi.org/10.1016/j.gene.2015.05.046)

Lanz RB, McKenna NJ, Onate SA, Albrecht U, Wong J, Tsai SY, Tsai MJ \& O'Malley BW 1999 A steroid receptor coactivator, SRA, functions as an RNA and is present in an SRC-1 complex. Cell 97 17-27. (https:// doi.org/10.1016/S0092-8674(00)80711-4)

Laxman B, Morris DS, Yu J, Siddiqui J, Cao J, Mehra R, Lonigro RJ, Tsodikov A, Wei JT, Tomlins SA, et al. 2008 A first-generation multiplex biomarker analysis of urine for the early detection of prostate cancer. Cancer Research 68 645-649. (https://doi. org/10.1158/0008-5472.CAN-07-3224)

Lee J, Park HY, Kim WW, Lee SJ, Jeong JH, Kang SH, Jung JH \& Chae YS 2017 Biological function of long noncoding RNA snaR in HER2positive breast cancer cells. Tumour Biology 391010428317707374. (https://doi.org/10.1177/1010428317707374)

Leti F \& DiStefano JK 2017 Long noncoding RNAs as diagnostic and therapeutic targets in type 2 diabetes and related complications. Genes 8 E207. (https://doi.org/10.3390/genes8080207)

Leygue E 2007 Steroid receptor RNA activator (SRA1): unusual bifaceted gene products with suspected relevance to breast cancer. Nuclear Receptor Signaling 5 e006. (https://doi.org/10.1621/nrs.05006) (c) 2018 Society for Endocrinology Published by Bioscientifica Ltd. Printed in Great Britain 
Li W, Notani D \& Rosenfeld MG $2016 a$ Enhancers as non-coding RNA transcription units: recent insights and future perspectives. Nature Reviews Genetics 17 207-223. (https://doi.org/10.1038/nrg.2016.4)

Li W, Zhai L, Wang H, Liu C, Zhang J, Chen W \& Wei Q $2016 b$ Downregulation of LncRNA GAS5 causes trastuzumab resistance in breast cancer. Oncotarget 7 27778-27786. (https://doi.org/10.18632/ oncotarget.8413)

Li X, Xiong X \& Yi C 2016c Epitranscriptome sequencing technologies: decoding RNA modifications. Nature Methods 14 23. (https://doi. org/10.1038/nmeth.4110)

Li J, Wang J, Zhong Y, Guo R, Chu D, Qiu H \& Yuan Z 2017a HOTAIR: a key regulator in gynecologic cancers. Cancer Cell International 1765. (https://doi.org/10.1186/s12935-017-0434-6)

Li JH, Zhang SQ, Qiu XG, Zhang SJ, Zheng SH \& Zhang DH 2017b Long non-coding RNA NEAT1 promotes malignant progression of thyroid carcinoma by regulating miRNA-214. International Journal of Oncology 50 708-716. (https://doi.org/10.3892/ijo.2016.3803)

Li W, Li N, Shi K \& Chen Q 2017c Systematic review and meta-analysis of the utility of long non-coding RNA GAS5 as a diagnostic and prognostic cancer biomarker. Oncotarget 8 66414-66425. (https://doi org/10.18632/oncotarget.19040)

Liang C, Li Y \& Luo J 2016 A novel method to detect functional microRNA regulatory modules by bicliques merging. IEEE/ACM Transactions on Computational Biology and Bioinformatics 13 549-556. (https://doi.org/10.1109/ТCBB.2015.2462370)

Liang HF, Zhang XZ, Liu BG, Jia GT \& Li WL 2017 Circular RNA circABCB10 promotes breast cancer proliferation and progression through sponging miR-1271. American Journal of Cancer Research 7 1566-1576.

Lima CR, Gomes CC \& Santos MF 2017 Role of microRNAs in endocrine cancer metastasis. Molecular and Cellular Endocrinology 456 62-75. (https://doi.org/10.1016/j.mce.2017.03.015)

Lin A, Li C, Xing Z, Hu Q, Liang K, Han L, Wang C, Hawke DH, Wang S, Zhang Y, et al. 2016 The LINK-A lncRNA activates normoxic HIF1alpha signalling in triple-negative breast cancer. Nature Cell Biology 18 213-224. (https://doi.org/10.1038/ncb3295)

Lin A, Hu Q, Li C, Xing Z, Ma G, Wang C, Li J, Ye Y, Yao J, Liang K, et al. 2017 The LINK-A lncRNA interacts with PtdIns(3,4,5)P3 to hyperactivate AKT and confer resistance to AKT inhibitors. Nature Cell Biology 19 238. (https://doi.org/10.1038/ncb3473)

Liu N, Parisien M, Dai Q, Zheng G, He C \& Pan T 2013 Probing N6-methyladenosine RNA modification status at single nucleotide resolution in mRNA and long noncoding RNA. RNA 19 1848-1856. (https://doi.org/10.1261/rna.041178.113)

Liu S, Sheng L, Miao H, Saunders TL, MacDougald OA, Koenig RJ \& Xu B 2014 SRA gene knockout protects against diet-induced obesity and improves glucose tolerance. Journal of Biological Chemistry $\mathbf{2 8 9}$ 13000-13009. (https://doi.org/10.1074/jbc.M114.564658)

Liu B, Sun L, Liu Q, Gong C, Yao Y, Lv X, Lin L, Yao H, Su F, Li D, et al. 2015 A cytoplasmic NF-кB interacting long noncoding RNA blocks ІкB phosphorylation and suppresses breast cancer metastasis. Cancer Cell 27 370-381. (https://doi.org/10.1016/j.ccell.2015.02.004)

Liu C, Wu H-T, Zhu N, Shi Y-N, Liu Z, Ao B-X, Liao D-F, Zheng X-L \& Qin L 2016 Steroid receptor RNA activator: biologic function and role in disease. Clinica Chimica Acta 459 137-146. (https://doi. org/10.1016/j.cca.2016.06.004)

Liz J \& Esteller M 2016 lncRNAs and microRNAs with a role in cancer development. Biochimica et Biophysica Acta (BBA): Gene Regulatory Mechanisms 1859 169-176. (https://doi.org/10.1016/j. bbagrm.2015.06.015)

Luo P, Liu XF, Wang YC, Li ND, Liao SJ, Yu MX, Liang CZ \& Tu JC 2017 Prognostic value of abnormally expressed lncRNAs in ovarian carcinoma: a systematic review and meta-analysis. Oncotarget $\mathbf{8}$ 23927-23936. (https://doi.org/10.18632/oncotarget.23311)

Luteijn MJ \& Ketting RF 2013 PIWI-interacting RNAs: from generation to transgenerational epigenetics. Nature Reviews Genetics 14 523-534. (https://doi.org/10.1038/nrg3495)
Ma L, Reinhardt F, Pan E, Soutschek J, Bhat B, Marcusson EG, TeruyaFeldstein J, Bell GW \& Weinberg RA 2010 Therapeutic silencing of miR-10b inhibits metastasis in a mouse mammary tumor model. Nature Biotechnology 28 341-347. (https://doi.org/10.1038/nbt.1618)

Macconaill LE \& Garraway LA 2010 Clinical implications of the cancer genome. Journal of Clinical Oncology 28 5219-5228. (https://doi. org/10.1200/JCO.2009.27.4944)

Malih S, Saidijam M \& Malih N 2015 A brief review on long noncoding RNAs: a new paradigm in breast cancer pathogenesis, diagnosis and therapy. Tumour Biology 37 1479-1485. (https://doi.org/10.1007/ s13277-015-4572-y)

Marrone AK, Beland FA \& Pogribny IP 2014 Noncoding RNA response to xenobiotic exposure: an indicator of toxicity and carcinogenicity. Expert Opinion on Drug Metabolism and Toxicology 10 1409-1422. (https://doi.org/10.1517/17425255.2014.954312)

Massillo C, Dalton GN, Farré PL, De Luca P \& De Siervi A 2017 Implications of microRNA dysregulation in the development of prostate cancer. Reproduction 154 R81-R97. (https://doi.org/10.1530/ REP-17-0322)

McKay DB, Xi L, Barthel KKB \& Cech TR 2014 Structure and function of steroid receptor RNA activator protein, the proposed partner of SRA noncoding RNA. Journal of Molecular Biology 426 1766-1785. (https:// doi.org/10.1016/j.jmb.2014.01.006)

Meng Q, Ren M, Li Y \& Song X 2016 LncRNA-RMRP acts as an oncogene in lung cancer. PLOS ONE 11 e0164845. (https://doi. org/10.1371/journal.pone.0164845)

Meng S, Zhou H, Feng Z, Xu Z, Tang Y, Li P \& Wu M 2017 CircRNA: functions and properties of a novel potential biomarker for cancer. Molecular Cancer 16 94. (https://doi.org/10.1186/s12943017-0663-2)

Mercer TR \& Mattick JS 2013 Structure and function of long noncoding RNAs in epigenetic regulation. Nature Structural and Molecular Biology 20 300-307. (https://doi.org/10.1038/nsmb.2480)

Miano V, Ferrero G, Reineri S, Caizzi L, Annaratone L, Ricci L, Cutrupi S, Castellano I, Cordero F \& De Bortoli M 2016 Luminal long non-coding RNAs regulated by estrogen receptor alpha in a ligand-independent manner show functional roles in breast cancer. Oncotarget 7 3201-3216. (https://doi.org/10.18632/ oncotarget.6420)

Mirza AH, Kaur S \& Pociot F 2017 Long non-coding RNAs as novel players in $\beta$ cell function and type 1 diabetes. Human Genomics 11 17. (https://doi.org/10.1186/s40246-017-0113-7)

Mondal T, Subhash S, Vaid R, Enroth S, Uday S, Reinius B, Mitra S, Mohammed A, James AR, Hoberg E, et al. 2015 MEG3 long noncoding RNA regulates the TGF-beta pathway genes through formation of RNA-DNA triplex structures. Nature Communications 6 7743. (https://doi.org/10.1038/ncomms8743)

Montagnana M, Benati M, Danese E, Giudici S, Perfranceschi M, Ruzzenenete O, Salvagno GL, Bassi A, Gelati M, Paviati E, et al. 2017 Aberrant microRNA expression in patients with endometrial cancer. International Journal of Gynecological Cancer 27 459-466. (https://doi. org/10.1097/IGC.0000000000000913)

Mori M, Triboulet R, Mohseni M, Schlegelmilch K, Shrestha K, Camargo Fernando D \& Gregory Richard I 2014 Hippo signaling regulates microprocessor and links cell-density-dependent miRNA biogenesis to cancer. Cell 156 893-906. (https://doi.org/10.1016/j. cell.2013.12.043

Morris KV \& Mattick JS 2014 The rise of regulatory RNA. Nature Reviews Genetics 15 423-437. (https://doi.org/10.1038/nrg3722)

Motterle A, Sanchez-Parra C \& Regazzi R 2016 Role of long non-coding RNAs in the determination of beta-cell identity. Diabetes, Obesity and Metabolism 18 (Supplement 1) 41-50. (https://doi.org/10.1111/ dom.12714)

Muluhngwi P \& Klinge CM 2015 Roles for miRNAs in endocrine resistance in breast cancer. Endocrine-Related Cancer 22 R279-R300. (https://doi.org/10.1530/ERC-15-0355)
(C) 2018 Society for Endocrinology Published by Bioscientifica Ltd. Printed in Great Britain 
Murugan AK, Munirajan AK \& Alzahrani AS 2017 Long noncoding RNAs: emerging players in thyroid cancer pathogenesis. EndocrineRelated Cancer 25 R59-R82. (https://doi.org/10.1530/ERC-17-0188)

Nagarajan S, Benito E, Fischer A \& Johnsen SA 2015 H4K12ac is regulated by estrogen receptor-alpha and is associated with BRD4 function and inducible transcription. Oncotarget 6 7305-7317.

Nakagawa S \& Kageyama Y 2014 Nuclear lncRNAs as epigenetic regulators-beyond skepticism. Biochimica et Biophysica Acta (BBA): Gene Regulatory Mechanisms 1839 215-222. (https://doi. org/10.1016/j.bbagrm.2013.10.009)

Nakagawa S, Ip JY, Shioi G, Tripathi V, Zong X, Hirose T \& Prasanth KV 2012 Malat1 is not an essential component of nuclear speckles in mice. RNA 18 1487-1499. (https://doi.org/10.1261/rna.033217.112)

Nelson AW, Groen AJ, Miller JL, Warren AY, Holmes KA, Tarulli GA, Tilley WD, Katzenellenbogen BS, Hawse JR, Gnanapragasam VJ, et al. 2017 Comprehensive assessment of estrogen receptor beta antibodies in cancer cell line models and tissue reveals critical limitations in reagent specificity. Molecular and Cellular Endocrinology 440 138-150. (https://doi.org/10.1016/j.mce.2016.11.016)

Nik-Zainal S, Davies H, Staaf J, Ramakrishna M, Glodzik D, Zou X, Martincorena I, Alexandrov LB, Martin S, Wedge DC, et al. 2016 Landscape of somatic mutations in 560 breast cancer wholegenome sequences. Nature 534 47-54. (https://doi.org/10.1038/ nature17676)

Niknafs YS, Han S, Ma T, Speers C, Zhang C, Wilder-Romans K, Iyer MK, Pitchiaya S, Malik R, Hosono Y, et al. 2016 The lncRNA landscape of breast cancer reveals a role for DSCAM-AS1 in breast cancer progression. Nature Communications 7 12791. (https://doi. org/10.1038/ncomms12791)

Novikova IV, Hennelly SP \& Sanbonmatsu KY 2012 Structural architecture of the human long non-coding RNA, steroid receptor RNA activator. Nucleic Acids Research 40 5034-5051. (https://doi. org/10.1093/nar/gks071)

O'Bryan S, Dong S, Mathis JM \& Alahari SK 2017 The roles of oncogenic miRNAs and their therapeutic importance in breast cancer. European Journal of Cancer 72 1-11. (https://doi.org/10.1016/j. ejca.2016.11.004)

O'Day E \& Lal A 2010 MicroRNAs and their target gene networks in breast cancer. Breast Cancer Research 12 201. (https://doi.org/10.1186/ bcr2484)

Ong MS, Cai W, Yuan Y, Leong HC, Tan TZ, Mohammad A, You ML, Arfuso F, Goh BC, Warrier S, et al. 2017 'Lnc'-ing Wnt in female reproductive cancers: therapeutic potential of long non-coding RNAs in Wnt signalling. British Journal of Pharmacology 174 4684-4700. (https://doi.org/10.1111/bph.13958)

Orellana EA, Tenneti S, Rangasamy L, Lyle LT, Low PS \& Kasinski AL 2017 FolamiRs: ligand-targeted, vehicle-free delivery of microRNAs for the treatment of cancer. Science Translational Medicine $\mathbf{9}$ eaam9327. (https://doi.org/10.1126/scitranslmed.aam9327)

Ørom Ulf A \& Shiekhattar R 2013 Long noncoding RNAs usher in a new era in the biology of enhancers. Cell 154 1190-1193. (https://doi. org/10.1016/j.cell.2013.08.028)

Pallante P, Battista S, Pierantoni GM \& Fusco A 2013 Deregulation of microRNA expression in thyroid neoplasias. Nature Reviews Endocrinology 10 88. (https://doi.org/10.1038/nrendo.2013.223)

Paraskevopoulou MD, Vlachos IS, Karagkouni D, Georgakilas G, Kanellos I, Vergoulis T, Zagganas K, Tsanakas P, Floros E, Dalamagas T, et al. 2016 DIANA-LncBase v2: indexing microRNA targets on non-coding transcripts. Nucleic Acids Research $\mathbf{4 4}$ D231-D238. (https://doi.org/10.1093/nar/gkv1270)

Patil DP, Chen C-K, Pickering BF, Chow A, Jackson C, Guttman M \& Jaffrey SR 2016 m6A RNA methylation promotes XIST-mediated transcriptional repression. Nature 537 369-373. (https://doi. org/10.1038/nature19342)

Peng N, Shi L, Zhang Q, Hu Y, Wang N \& Ye H 2017a Microarray profiling of circular RNAs in human papillary thyroid carcinoma.
PLOS ONE 12 e0170287. (https://doi.org/10.1371/journal. pone.0170287)

Peng WX, Koirala P \& Mo YY $2017 b$ LncRNA-mediated regulation of cell signaling in cancer. Oncogene 36 5661-5667. (https://doi. org/10.1038/onc.2017.184)

Piatek MJ \& Werner A 2014 Endogenous siRNAs: regulators of internal affairs. Biochemical Society Transactions 42 1174. (https://doi. org/10.1042/BST20140068)

Pickard MR \& Williams GT 2014 Regulation of apoptosis by long noncoding RNA GAS5 in breast cancer cells: implications for chemotherapy. Breast Cancer Research and Treatment 145 359-370. (https://doi.org/10.1007/s10549-014-2974-y)

Pishkari S, Paryan M, Hashemi M, Baldini E \& Mohammadi-Yeganeh S 2018 The role of microRNAs in different types of thyroid carcinoma: a comprehensive analysis to find new miRNA supplementary therapies. Journal of Endocrinological Investigation 41 269-283.

Piwecka M, Glažar P, Hernandez-Miranda LR, Memczak S, Wolf SA, Rybak-Wolf A, Filipchyk A, Klironomos F, Cerda Jara CA, Fenske P, et al. 2017 Loss of a mammalian circular RNA locus causes miRNA deregulation and affects brain function. Science $\mathbf{3 5 7}$ eaam8526. (https://doi.org/10.1126/science.aam8526)

Prensner JR, Chen W, Han S, Iyer MK, Cao Q, Kothari V, Evans JR, Knudsen KE, Paulsen MT, Ljungman M, et al. 2014 The long noncoding RNA PCAT-1 promotes prostate cancer cell proliferation through cMyc. Neoplasia 16 900-908. (https://doi.org/10.1016/j. neo.2014.09.001)

Qi P, Zhou X-Y \& Du X 2016 Circulating long non-coding RNAs in cancer: current status and future perspectives. Molecular Cancer 15 39. (https://doi.org/10.1186/s12943-016-0524-4)

Qian K, Liu G, Tang Z, Hu Y, Fang Y, Chen Z \& Xu X 2017 The long non-coding RNA NEAT1 interacted with miR-101 modulates breast cancer growth by targeting EZH2. Archives of Biochemistry and Biophysics 615 1-9. (https://doi.org/10.1016/j.abb.2016.12.011)

Rackham O, Shearwood AM, Mercer TR, Davies SM, Mattick JS \& Filipovska A 2011 Long noncoding RNAs are generated from the mitochondrial genome and regulated by nuclear-encoded proteins. RNA 17 2085-2093. (https://doi.org/10.1261/rna.029405.111)

Rashid F, Shah A \& Shan G 2016 Long non-coding RNAs in the cytoplasm. Genomics, Proteomics and Bioinformatics 14 73-80. (https://doi.org/10.1016/j.gpb.2016.03.005)

Redfern AD, Colley SM, Beveridge DJ, Ikeda N, Epis MR, Li X, Foulds CE, Stuart LM, Barker A, Russell VJ, et al. 2013 RNA-induced silencing complex (RISC) Proteins PACT, TRBP, and Dicer are SRA binding nuclear receptor coregulators. PNAS 110 6536-6541. (https://doi. org/10.1073/pnas.1301620110)

Rehmsmeier M, Steffen P, Hochsmann M \& Giegerich R 2004 Fast and effective prediction of microRNA/target duplexes. RNA $\mathbf{1 0}$ 1507-1517. (https://doi.org/10.1261/rna.5248604)

Ren S, Liu Y, Xu W, Sun Y, Lu J, Wang F, Wei M, Shen J, Hou J, Gao X, et al. 2013 Long noncoding RNA MALAT-1 is a new potential therapeutic target for castration resistant prostate cancer. Journal of Urology 190 2278-2287. (https://doi.org/10.1016/j.juro.2013.07.001)

Ren Q, Liang J, Wei J, Basturk O, Wang J, Daniels G, Gellert LL, Li Y, Shen Y, Osman I, et al. 2014 Epithelial and stromal expression of miRNAs during prostate cancer progression. American Journal of Translational Research 6 329-339.

Rheinbay E, Parasuraman P, Grimsby J, Tiao G, Engreitz JM, Kim J, Lawrence MS, Taylor-Weiner A, Rodriguez-Cuevas S, Rosenberg M, et al. 2017 Recurrent and functional regulatory mutations in breast cancer. Nature 547 55-60. (https://doi.org/10.1038/nature22992)

Ring A \& Dowsett M 2004 Mechanisms of tamoxifen resistance. Endocrine-Related Cancer 11 643-658. (https://doi.org/10.1677/ erc.1.00776)

Rinn JL \& Chang HY 2012 Genome regulation by long noncoding RNAs. Annual Review of Biochemistry 81 145-166. (https://doi. org/10.1146/annurev-biochem-051410-092902)
(C) 2018 Society for Endocrinology Published by Bioscientifica Ltd. Printed in Great Britain 
Rinn J \& Guttman M 2014 RNA and dynamic nuclear organization. Science 345 1240-1241. (https://doi.org/10.1126/science.1252966)

Rinn JL, Kertesz M, Wang JK, Squazzo SL, Xu X, Brugmann SA, Goodnough LH, Helms JA, Farnham PJ, Segal E, et al. 2007 Functional demarcation of active and silent chromatin domains in human HOX loci by noncoding RNAs. Cell 129 1311-1323. (https:// doi.org/10.1016/j.cell.2007.05.022)

Roden C, Gaillard J, Kanoria S, Rennie W, Barish S, Cheng J, Pan W, Liu J, Cotsapas C, Ding Y, et al. 2017 Novel determinants of mammalian primary microRNA processing revealed by systematic evaluation of hairpin-containing transcripts and human genetic variation. Genome Research 27 374-384. (https://doi.org/10.1101/ gr.208900.116)

Rosenberg M, Blum R, Kesner B, Maier VK, Szanto A \& Lee JT 2017 Denaturing CLIP, dCLIP, pipeline identifies discrete RNA footprints on chromatin-associated proteins and reveals that $\mathrm{CBX} 7$ targets $3^{\prime}$ UTRs to regulate mRNA expression. Cell Systems 5 368.e315-385. e315. (https://doi.org/10.1016/i.cels.2017.09.014)

Ru Y, Kechris KJ, Tabakoff B, Hoffman P, Radcliffe RA, Bowler R, Mahaffey S, Rossi S, Calin GA, Bemis L, et al. 2015 The multiMiR R package and database: integration of microRNA-target interactions along with their disease and drug associations. Nucleic Acids Research 42 e133. (https://doi.org/10.1093/nar/gku631)

Ruivo CF, Adem B, Silva M \& Melo SA 2017 The biology of cancer exosomes: insights and new perspectives. Cancer Research $\mathbf{7 7} 6480$ (https://doi.org/10.1158/0008-5472.CAN-17-0994)

Rutter MM, Jha P, Schultz KA, Sheil A, Harris AK, Bauer AJ, Field AL, Geller J \& Hill DA 2016 DICER1 mutations and differentiated thyroid carcinoma: evidence of a direct association. Journal of Clinical Endocrinology and Metabolism 101 1-5. (https://doi. org/10.1210/jc.2015-2169)

Ryder M, Ghossein RA, Ricarte-Filho JCM, Knauf JA \& Fagin JA 2008 Increased density of tumor-associated macrophages is associated with decreased survival in advanced thyroid cancer. Endocrine-Related Cancer 15 1069-1074. (https://doi.org/10.1677/ERC-08-0036)

Saini HK, Griffiths-Jones S \& Enright AJ 2007 Genomic analysis of human microRNA transcripts. PNAS 104 17719-17724. (https://doi. org/10.1073/pnas.0703890104)

Saiselet M, Pita JM, Augenlicht A, Dom G, Tarabichi M, Fimereli D, Dumont JE, Detours V \& Maenhaut C 2016 miRNA expression and function in thyroid carcinomas: a comparative and critical analysis and a model for other cancers. Oncotarget 7 52475-52492. (https:// doi.org/10.18632/oncotarget.9655)

Salameh A, Lee AK, Cardó-Vila M, Nunes DN, Efstathiou E, Staquicini FI, Dobroff AS, Marchiò S, Navone NM, Hosoya H, et al. 2015 PRUNE2 is a human prostate cancer suppressor regulated by the intronic long noncoding RNA PCA3. PNAS 112 8403-8408. (https://doi. org/10.1073/pnas.1507882112)

Sansone P, Savini C, Kurelac I, Chang Q, Amato LB, Strillacci A, Stepanova A, Iommarini L, Mastroleo C, Daly L, et al. 2017 Packaging and transfer of mitochondrial DNA via exosomes regulate escape from dormancy in hormonal therapy-resistant breast cancer. PNAS 114 E9066-E9075. (https://doi.org/10.1073/pnas.1704862114)

Schouten PC, Vollebergh MA, Opdam M, Jonkers M, Loden M, Wesseling J, Hauptmann M \& Linn SC 2016 High XIST and low 53BP1 expression predict poor outcome after high-dose alkylating chemotherapy in patients with a BRCA1-like breast cancer. Molecular Cancer Therapeutics 15 190. (https://doi.org/10.1158/1535-7163.MCT15-0470)

Siegel RL, Miller KD \& Jemal A 2017 Cancer Statistics, 2017. CA: A Cancer Journal for Clinicians 67 7-30.

Smith B, Agarwal P \& Bhowmick NA 2017 MicroRNA applications for prostate, ovarian and breast cancer in the era of precision medicine. Endocrine-Related Cancer 24 R157-R172. (https://doi.org/10.1530/ ERC-16-0525)
Smolle MA, Bullock MD, Ling H, Pichler M \& Haybaeck J 2015 Long non-coding RNAs in endometrial carcinoma. International Journal of Molecular Sciences 16 26463-26472. (https://doi.org/10.3390/ ijms161125962)

Sowalsky AG, Xia Z, Wang L, Zhao H, Chen S, Bubley GJ, Balk SP \& Li W 2015 Whole transcriptome sequencing reveals extensive unspliced mRNA in metastatic castration-resistant prostate cancer. Molecular Cancer Research 13 98. (https://doi.org/10.1158/1541-7786. MCR-14-0273)

Srivastava SK, Ahmad A, Zubair H, Miree O, Singh S, Rocconi RP, Scalici J \& Singh AP 2017 MicroRNAs in gynecological cancers: Small molecules with big implications. Cancer Letters 407 123-138. (https://doi.org/10.1016/j.canlet.2017.05.011)

Su X, Malouf GG, Chen Y, Zhang J, Yao H, Valero V, Weinstein JN, Spano JP, Meric-Bernstam F, Khayat D, et al. 2014 Comprehensive analysis of long non-coding RNAs in human breast cancer clinical subtypes. Oncotarget 5 9864-9876.

Sun KX, Wu DD, Chen S, Zhao Y \& Zong ZH $2017 a$ LncRNA MEG3 inhibit endometrial carcinoma tumorigenesis and progression through PI3K pathway. Apoptosis 22 1543-1552. (https://doi. org/10.1007/s10495-017-1426-7)

Sun MY, Zhu JY, Zhang CY, Zhang M, Song YN, Rahman K, Zhang LJ \& Zhang H 2017b Autophagy regulated by lncRNA HOTAIR contributes to the cisplatin-induced resistance in endometrial cancer cells. Biotechnology Letters 39 1477-1484. (https://doi.org/10.1007/s10529017-2392-4)

Takenaka K, Chen BJ, Modesitt SC, Byrne FL, Hoehn KL \& Janitz M 2016 The emerging role of long non-coding RNAs in endometrial cancer. Cancer Genetics 209 445-455. (https://doi.org/10.1016/j. cancergen.2016.09.005)

Theodorou V, Stark R, Menon S \& Carroll JS 2013 GATA3 acts upstream of FOXA1 in mediating ESR1 binding by shaping enhancer accessibility. Genome Research 23 12-22. (https://doi.org/10.1101/ gr.139469.112)

Torres A, Kozak J, Korolczuk A, Wdowiak P, Domanska-Glonek E, Maciejewski R \& Torres K 2016 In vitro and in vivo activity of miR92a-Locked Nucleic Acid (LNA)-Inhibitor against endometrial cancer. BMC Cancer 16 822. (https://doi.org/10.1186/s12885-016-2867-z)

Tripathi V, Ellis JD, Shen Z, Song DY, Pan Q, Watt AT, Freier SM, Bennett CF, Sharma A, Bubulya PA, et al. 2010 The nuclear-retained noncoding RNA MALAT1 regulates alternative splicing by modulating SR splicing factor phosphorylation. Molecular Cell 39 925-938. (https://doi.org/10.1016/j.molcel.2010.08.011)

Trisciuoglio D, Desideri M, Farini V, De Luca T, Di Martile M, Tupone MG, Urbani A, D’Aguanno S \& Del Bufalo D 2016 Affinity purification-mass spectrometry analysis of bcl-2 interactome identified SLIRP as a novel interacting protein. Cell Death and Disease 7 e2090. (https://doi.org/10.1038/cddis.2015.357)

Van Nostrand EL, Pratt GA, Shishkin AA, Gelboin-Burkhart C, Fang MY, Sundararaman B, Blue SM, Nguyen TB, Surka C, Elkins K, et al. 2016 Robust transcriptome-wide discovery of RNA-binding protein binding sites with enhanced CLIP (eCLIP). Nature Methods $\mathbf{1 3}$ 508-514. (https://doi.org/10.1038/nmeth.3810)

van Schooneveld E, Wildiers H, Vergote I, Vermeulen PB, Dirix LY \& Van Laere SJ 2015 Dysregulation of microRNAs in breast cancer and their potential role as prognostic and predictive biomarkers in patient management. Breast Cancer Research 17 21. (https://doi. org/10.1186/s13058-015-0526-y)

Vanacore D, Boccellino M, Rossetti S, Cavaliere C, D'Aniello C, Di Franco R, Romano FJ, Montanari M, La Mantia E, Piscitelli R, et al. 2017 Micrornas in prostate cancer: an overview. Oncotarget 8 50240-50251. (https://doi.org/10.18632/oncotarget.16933)

Vendramin R, Marine JC \& Leucci E 2017 Non-coding RNAs: the dark side of nuclear-mitochondrial communication. EMBO Journal $\mathbf{3 6}$ 1123-1133. (https://doi.org/10.15252/embj.201695546)
2018 Society for Endocrinology Published by Bioscientifica Ltd. Printed in Great Britain 
Venkatesh T, Suresh PS \& Tsutsumi R 2015 Non-coding RNAs: functions and applications in endocrine-related cancer. Molecular and Cellular Endocrinology 416 88-96. (https://doi.org/10.1016/j.mce.2015.08.026)

Vidaurre S, Fitzpatrick C, Burzio VA, Briones M, Villota C, Villegas J, Echenique J, Oliveira-Cruz L, Araya M, Borgna V, et al. 2014 Downregulation of the antisense mitochondrial non-coding RNAs (ncRNAs) is a unique vulnerability of cancer cells and a potential target for cancer therapy. Journal of Biological Chemistry 289 27182-27198. (https://doi.org/10.1074/jbc.M114.558841)

Wan L, Kong J, Tang J, Wu Y, Xu E, Lai M \& Zhang H 2016 HOTAIRM1 as a potential biomarker for diagnosis of colorectal cancer functions the role in the tumour suppressor. Journal of Cellular and Molecular Medicine 20 2036-2044. (https://doi.org/10.1111/jcmm.12892)

Wang F, Ren S, Chen R, Lu J, Shi X, Zhu Y, Zhang W, Jing T, Zhang C, Shen J, et al. 2014 Development and prospective multicenter evaluation of the long noncoding RNA MALAT-1 as a diagnostic urinary biomarker for prostate cancer. Oncotarget 5 11091-11102.

Wang J, Zhao X, Guo Z, Ma X, Song Y \& Guo Y 2017a Regulation of NEAT1/miR-214-3p on the growth, migration and invasion of endometrial carcinoma cells. Archives of Gynecology and Obstetrics 295 1469-1475. (https://doi.org/10.1007/s00404-017-4365-1)

Wang S, Liang K, Hu Q, Li P, Song J, Yang Y, Yao J, Mangala LS, Li C, Yang W, et al. 2017b JAK2-binding long noncoding RNA promotes breast cancer brain metastasis. Journal of Clinical Investigation 127 91553. (https://doi.org/10.1172/JCI91553)

Wang X, Ruan Y, Wang X, Zhao W, Jiang Q, Jiang C, Zhao Y, Xu Y, Sun F, Zhu Y, et al. 2017c Long intragenic non-coding RNA lincRNA-p21 suppresses development of human prostate cancer. Cell Proliferation $\mathbf{5 0}$ e12318.

Wang X, Xu Y, Wang X, Jiang C, Han S, Dong K, Shen M \& Xu D 2017d LincRNA-p21 suppresses development of human prostate cancer through inhibition of PKM2. Cell Proliferation 50 e12395.

Warburton AJ \& Boone DN 2017 Insights from global analyses of long noncoding RNAs in breast cancer. Current Pathobiology Reports 5 23-34. (https://doi.org/10.1007/s40139-017-0122-1)

Watanabe T \& Lin H 2014 Posttranscriptional regulation of gene expression by piwi proteins and piRNAs. Molecular Cell 56 18-27. (https://doi.org/10.1016/j.molcel.2014.09.012)

Weidle UH, Birzele F, Kollmorgen G \& Ruger R 2017 Long non-coding RNAs and their role in metastasis. Cancer Genomics and Proteomics 14 143-160. (https://doi.org/10.21873/cgp.20027)

Wolf JB 2013 Principles of transcriptome analysis and gene expression quantification: an RNA-seq tutorial. Molecular Ecology Resources 13 559-572. (https://doi.org/10.1111/1755-0998.12109)

Wu Y, Zhang L, Wang Y, Li H, Ren X, Wei F, Yu W, Wang X, Zhang L, Yu J, et al. 2014 Long noncoding RNA HOTAIR involvement in cancer. Tumor Biology 35 9531-9538. (https://doi.org/10.1007/ s13277-014-2523-7)

Xiyuan L, Dechao B, Liang S, Yang W, Shuangsang F, Hui L, Haitao L, Chunlong L, Wenzheng F, Runsheng C, et al. 2017 Using the NONCODE database resource. Current Protocols in Bioinformatics $\mathbf{5 8}$ 12.16.11-12.16.19. (https://doi.org/10.1002/cpbi.25)

Xu CG, Yang MF, Ren YQ, Wu CH \& Wang LQ 2016 Exosomes mediated transfer of lncRNA UCA1 results in increased tamoxifen resistance in breast cancer cells. European Review for Medical and Pharmacological Sciences 20 4362-4368.

Xu W, Chang J, Du X \& Hou J 2017 Long non-coding RNA PCAT-1 contributes to tumorigenesis by regulating FSCN1 via miR-145-5p in prostate cancer. Biomedicine and Pharmacotherapy 95 1112-1118. (https://doi.org/10.1016/j.biopha.2017.09.019)

Xue D, Zhou C, Lu H, Xu R, Xu X \& He X 2016 a LncRNA GAS5 inhibits proliferation and progression of prostate cancer by targeting miR-103 through AKT/mTOR signaling pathway. Tumor Biology 37 16187-16197. (https://doi.org/10.1007/s13277-016-5429-8)

Xue X, Yang YA, Zhang A, Fong KW, Kim J, Song B, Li S, Zhao JC \& Yu J $2016 b$ LncRNA HOTAIR enhances ER signaling and confers tamoxifen resistance in breast cancer. Oncogene 35 2746-2755. (https://doi.org/10.1038/onc.2015.340)

Xue M, Zhuo Y \& Shan B 2017 MicroRNAs, long noncoding RNAs, and their functions in human disease. Methods in Molecular Biology 1617 1-25. (https://doi.org/10.1007/978-1-4939-7046-9_1)

Yahya SMM \& Elsayed GH 2015 A summary for molecular regulations of miRNAs in breast cancer. Clinical Biochemistry 48 388-396. (https:// doi.org/10.1016/j.clinbiochem.2014.12.013)

Yamazaki T \& Hirose T 2015 The building process of the functional paraspeckle with long non-coding RNAs. Frontiers in Bioscience 7 1-41. (https://doi.org/10.2741/s420)

Yang F, Zhang H, Mei Y \& Wu M 2014 Reciprocal regulation of HIF-1 $\alpha$ and LincRNA-p21 modulates the warburg effect. Molecular Cell $\mathbf{5 3}$ 88-100. (https://doi.org/10.1016/j.molcel.2013.11.004)

Yang F, Ning Z, Ma L, Liu W, Shao C, Shu Y \& Shen H 2017a Exosomal miRNAs and miRNA dysregulation in cancer-associated fibroblasts. Molecular Cancer 16 148. (https://doi.org/10.1186/ s12943-017-0718-4)

Yang K, Hou Y, Li A, Li Z, Wang W, Xie H, Rong Z, Lou G \& Li K 2017b Identification of a six-lncRNA signature associated with recurrence of ovarian cancer. Scientific Reports 7 752. (https://doi.org/10.1038/ s41598-017-00763-y)

Yang Y, Fan X, Mao M, Song X, Wu P, Zhang Y, Jin Y, Yang Y, Chen L-L, Wang Y, et al. 2017c Extensive translation of circular RNAs driven by N6-methyladenosine. Cell Research 27 626-641. (https://doi. org/10.1038/cr.2017.31)

Yoo SK, Lee S, Kim SJ, Jee HG, Kim BA, Cho H, Song YS, Cho SW, Won JK, Shin JY, et al. 2016 Comprehensive analysis of the transcriptional and mutational landscape of follicular and papillary thyroid cancers. PLoS Genetics 12 e1006239. (https://doi.org/10.1371/ journal.pgen.1006239)

Yoon J-H, Abdelmohsen K \& Gorospe M 2014 Functional interactions among microRNAs and long noncoding RNAs. Seminars in Cell and Developmental Biology 34 9-14. (https://doi.org/10.1016/j. semcdb.2014.05.015)

Zhang B, Arun G, Mao Yuntao S, Lazar Z, Hung G, Bhattacharjee G, Xiao X, Booth Carmen J, Wu J, Zhang C, et al. 2012 The lncRNA Malat1 is dispensable for mouse development but its transcription plays a cis-regulatory role in the adult. Cell Reports 2 111-123. (https://doi.org/10.1016/j.celrep.2012.06.003)

Zhang Z, Zhu Z, Watabe K, Zhang X, Bai C, Xu M, Wu F \& Mo YY 2013 Negative regulation of lncRNA GAS5 by miR-21. Cell Death and Differentiation 20 1558-1568. (https://doi.org/10.1038/cdd.2013.110)

Zhang B, Xing X, Li J, Lowdon RF, Zhou Y, Lin N, Zhang B, Sundaram V, Chiappinelli KB, Hagemann IS, et al. 2014 Comparative DNA methylome analysis of endometrial carcinoma reveals complex and distinct deregulation of cancer promoters and enhancers. BMC Genomics 15 868. (https://doi.org/10.1186/1471-2164-15-868)

Zhang A, Zhao Jonathan C, Kim J, Fong K-W, Yang Yeqing A, Chakravarti D, Mo Y-Y \& Yu J 2015 LncRNA HOTAIR enhances the androgen-receptor-mediated transcriptional program and drives castration-resistant prostate cancer. Cell Reports 13 209-221. (https:// doi.org/10.1016/j.celrep.2015.08.069)

Zhang A, Zhang J, Kaipainen A, Lucas JM \& Yang H $2016 a$ Long noncoding RNA: a newly deciphered 'code' in prostate cancer. Cancer Letters 375 323-330. (https://doi.org/10.1016/j.canlet.2016.03.003)

Zhang W, Le TD, Liu L, Zhou ZH \& Li J $2016 b$ Predicting miRNA targets by integrating gene regulatory knowledge with expression profiles. PLOS ONE 11 e0152860. (https://doi.org/10.1371/journal. pone.0152860)

Zhang JJ, Guo SH \& Jia BQ 2016c Down-regulation of long non-coding RNA MEG3 serves as an unfavorable risk factor for survival of patients with breast cancer. European Review for Medical and Pharmacological Sciences 20 5143-5147.

Zhang Y, Wagner EK, Guo X, May I, Cai Q, Zheng W, He C \& Long J $2016 d$ Long intergenic non-coding RNA expression signature in (c) 2018 Society for Endocrinology Published by Bioscientifica Ltd. Printed in Great Britain 
human breast cancer. Scientific Reports 6 37821. (https://doi. org/10.1038/srep37821)

Zhang D, Cao J, Zhong Q, Zeng L, Cai C, Lei L, Zhang W \& Liu F 2017 a Long noncoding RNA PCAT-1 promotes invasion and metastasis via the miR-129-5p-HMGB1 signaling pathway in hepatocellular carcinoma. Biomedicine and Pharmacotherapy 95 1187-1193. (https:// doi.org/10.1016/j.biopha.2017.09.045)

Zhang R, Hardin H, Huang W, Chen J, Asioli S, Righi A, Maletta F, Sapino A \& Lloyd RV 2017b MALAT1 long non-coding RNA expression in thyroid tissues: analysis by in situ hybridization and Real-time PCR. Endocrine Pathology 28 7-12. (https://doi.org/10.1007/ s12022-016-9453-4)

Zhang W, Shi S, Jiang J, Li X, Lu H \& Ren F 2017c LncRNA MEG3 inhibits cell epithelial-mesenchymal transition by sponging miR-421 targeting E-cadherin in breast cancer. Biomedicine and Pharmacotherapy 91 312-319. (https://doi.org/10.1016/j.biopha.2017.04.085)

Zhang Y, Yu S, Jiang L, Wang X \& Song X 2017d HOTAIR is a promising novel biomarker in patients with thyroid cancer. Experimental and Therapeutic Medicine 13 2274-2278. (https://doi.org/10.3892/ etm.2017.4231)

Zhang X, Hamblin MH \& Yin KJ 2017e The long noncoding RNA Malat1: its physiological and pathophysiological functions. RNA Biology 14 1705-1714. (https://doi.org/10.1080/15476286.2017.1358347)

Zhao Y, Yang Y, Trovik J, Sun K, Zhou L, Jiang P, Lau TS, Hoivik EA, Salvesen HB, Sun H, et al. 2014 A novel wnt regulatory axis in endometrioid endometrial cancer. Cancer Research 74 5103-5117. (https://doi.org/10.1158/0008-5472.CAN-14-0427)

Zheng P, Xiong Q, Wu Y, Chen Y, Chen Z, Fleming J, Gao D, Bi L \& Ge F 2015 Quantitative proteomics analysis reveals novel insights into mechanisms of action of long noncoding RNA hox transcript antisense intergenic RNA (HOTAIR) in HeLa Cells. Molecular and Cellular Proteomics 14 1447-1463. (https://doi.org/10.1074/mcp. M114.043984)

Zhou KI, Parisien M, Dai Q, Liu N, Diatchenko L, Sachleben JR \& Pan T 2016 N6-methyladenosine modification in a long noncoding RNA hairpin predisposes its conformation to protein binding. Journal of Molecular Biology 428 822-833. (https://doi.org/10.1016/j. jmb.2015.08.021)

Zhou W, Ye X-L, Xu J, Cao M-G, Fang Z-Y, Li L-Y, Guan G-H, Liu Q Qian Y-H \& Xie D 2017 The lncRNA H19 mediates breast cancer cell plasticity during EMT and MET plasticity by differentially sponging $\mathrm{miR}-200 \mathrm{~b} / \mathrm{c}$ and let-7b. Science Signaling 10 eaak9557. (https://doi. org/10.1126/scisignal.aak9557)

Zhu H, Lv Z, An C, Shi M, Pan W, Zhou L, Yang W \& Yang M 2016 Onco-lncRNA HOTAIR and its functional genetic variants in papillary thyroid carcinoma. Scientific Reports 6 31969. (https://doi. org/10.1038/srep31969)

Ziegler C \& Kretz M 2017 The more the merrier-complexity in long noncoding RNA loci. Frontiers in Endocrinology 8 90. (https://doi. org/10.3389/fendo.2017.00090)

Received in final form 18 December 2017

Accepted 12 February 2018

Accepted Preprint published online 12 February 2018
(C) 2018 Society for Endocrinology Published by Bioscientifica Ltd. Printed in Great Britain 